\title{
الأحاديث النبوية الواردة في غيرة النساء جمعاً وتخريجاً ودراسة
}

\author{
إعداد الاكتور / معلا بن مساعد بن عزام الميلبي \\ جامعة الحدود الثدالية \\ مستخلص تتاول هذا البحث تعريف الغيرة لغة واصطلاحاً ، وجُمت فيه الأحاديث النبوية الواردة في غيرة النساء

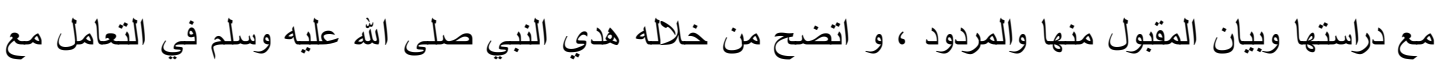 \\ النساء حال الغيرة. \\ الكلمات الكفتاحة: الغيرة - الحديث النبوي الثريف- النبي صلى الله عليه وسلم - النساء في الإسلام.
}

وفي الغالب فإن لغيرة المرأة أسباباً وبواعث، فهي

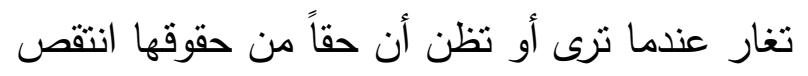
أو سلب، أو حال المقارنة أو المنافسة مع غيرها، إلى غير ذلك من دواعي الغيرة فيها, وأنثد ما تغار

من بنات جنسها، وأكثر ما تغار عليه زوجها.

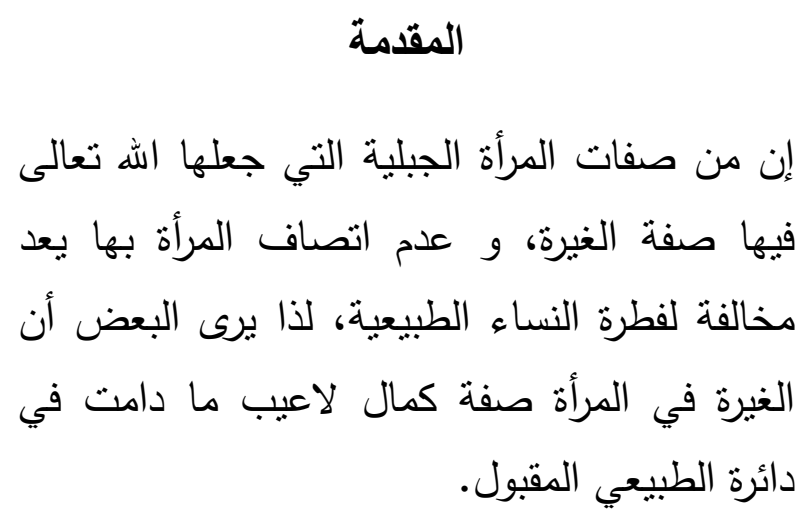


والمهم ألا تتجاوز المرأة في الغيرة وما ينتج عنها أولاً : المقدمة وهي هذه، وفيها: خطة البحث،

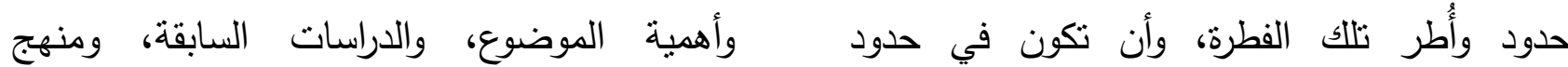
المسموح به والمعفو عنه شرعاً، غير أن الكثير من البحث.

ثانياً : التمهيد، وفيه: تعريف الغيرة لغة واصطلاحاً. النساء تتعدى ذلك فتدفعها غيرتها المفرطة إلى فعل ثالثاً :المبحث الأول/ ما جاء في غيرة أمهات

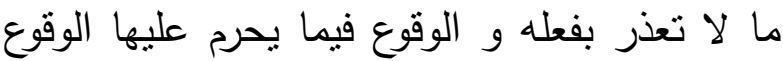

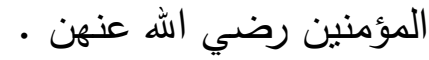

رابعاً: المبحث الثاني/ ما جاء في غيرة غير أمهات

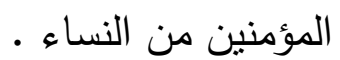

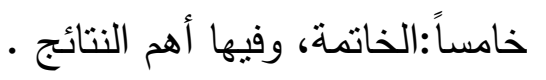

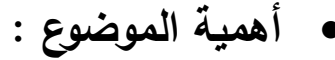

تتجلى أهمية هذا البحث في أمور منها:

1. أنه يعد جزءاً حديثياً جمع فيه من الأحاديث

النبوية في موضوعه مالم يجمع في غيره ،

مع بيان صحيحها من سقيمها.

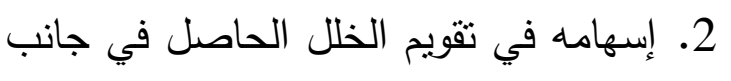

الغيرة لدى كثير من النساء خاصة في هذا الزمان الذي رأينا فيه وسمعنا من دفعتها

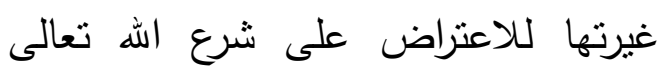

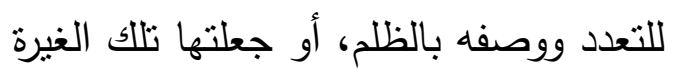
تلدق أنواعاً من الأذى بالضرائر والأزواج وغيرهم، منل القتل والإحراق والسحر . 3. بيانه للمنهج الصحيح السليم في التعامل

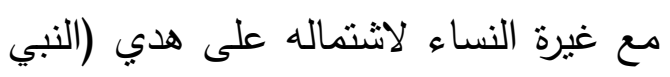
صلى الله عليه وسلم ) في ذلك . كما أن تقهم الآخرين وخاصة الأزواج لذلك أمر

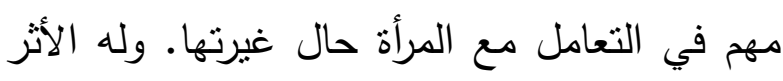
البالغ في تقويم ومعالجة ما قد ينتج عنها.

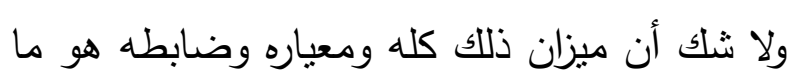
جاء عن الرسول صلى اله عليه وسلم فيما ينطلق في غيرة النساء. فالخير كل الخير في هديه ومتابعة النداء لذا رأيت أن أكتب بحثا مختصراً أجمع فيه

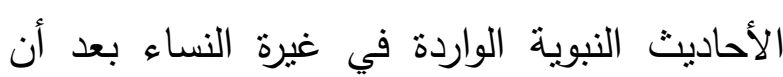
كانت مبثوثة في كتب السنة لتصبح في جزء واحد يكون بعد نشره في متتاول الأيدي رجاء أن ينفع الله تعالى به في بابه، وجعلت عنوانه " الأحاديث النبوية الواردة في غيرة النساء جمعاً وتخريجاً ودراسة"

وقد تكوَّن من هذه المقدمة، وتمهيد، و مبحثين، وخاتمة، وفهرس للمصادر ، وقد جاء ذلك كله على لـى

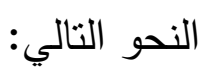


واحد منها، فإني أحكم على الإسناد لا على الحديث.

- تكلمت على من به علة من رجال الإسناد فقط و بينت علته. - علقت على ما رأيت أنه يحتاج إلى تعليق من الأحاديث المقبولة دون الضعيفة.

- بينت الغريب من كتب غريب الحديث إن تيسر، وإلا فمن كتب المعاجم. - ضبطت المشكل وعرفت بما يحتاج إلى تعريف

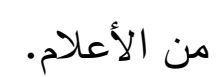

التمهيد

\section{• تعريف الغيرة}

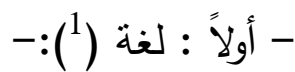

الغَيَرَة : بفتح الغين المعجمة وسكون الياء وفتح الراء، مصدر قولك غار الرجل على أهله يغار غيرا

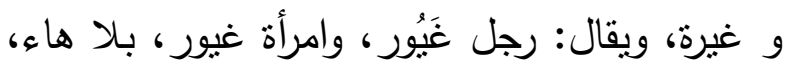

ينظر : مختار الصحاح 203/1 ، النهاية في غريب الأثر

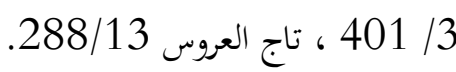

• الدراسات السابقة

لا نوجد دراسة سابقة تتاولت جمع الأحاديث النبوية الواردة في غيرة النساء وتخريجها ودراسة أسانيدها والحكم عليها، إلا ما ذكر فقط في أبواب غيرة النساء أو غيرها من أبواب الغيرة ضمن أبواب بعض الكتب المصنفة في الأحاديث النبوية ،غير أن الأحاديث الواردة في كل منها قليلة جداً.

- جمعت كل ما وققت عليه مما ورد في غيرة النساء من الأحاديث النبوية . ماث

- الحديث إن كان في الصحيحين فإني أكتفي بهما وأقدم صاحب اللفظ منهما .

- وإذا كان في أحدهما فقط أذكر معه بعض المراجع وأقدمه، ما لم يكن معه صاحب كتاب روى صاحب الصحيح الحديث من طريقه فإني إذن أقدم صاحب ذللك الكتاب لعلو إسناده. - الحديث إذا كان مكرراً في الصحيحين أو في أحدهما فإنني أذكر ما كان في أقرب الأبواب إن فكراب لموضوع البحث أو ما اتفق عليه الثيخان، وقد

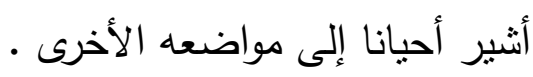
- أجتهذ في الحكم على الأحاديث من حيث الصحة والضعف، و ما لم أقف له إلا على إسناد 
المبحث الأول/ما جاء في غيرة أمهات

المؤمنين رضي الله عنهن .

1. عن عائشة رضي الله عنها ، قالت :) ران

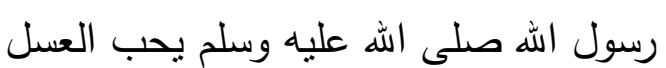

والحلــوى، وكـان إذا انصـرف مـن العصـر

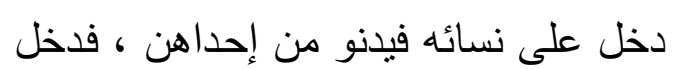

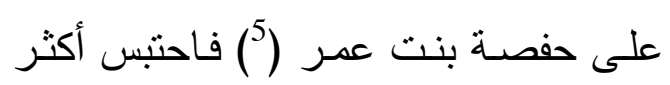

ما كان يحتبس ، فغرت فسألت عن ذللك ،

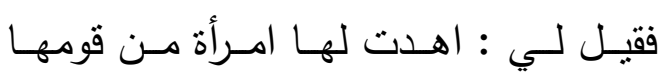

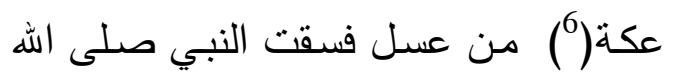

عليـه وسـلم منـه شـربة ـ فقلـت : أمـا واله فله

لنحتالن له ، فقلت لسودة بنت زمعة( $\left.)^{7}\right)^{7}$ إنها

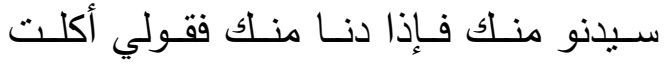

(5) هي أم المؤمنين حفصة بنت عمر بن الخطاب رضي الله

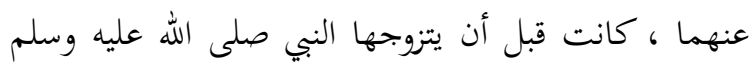

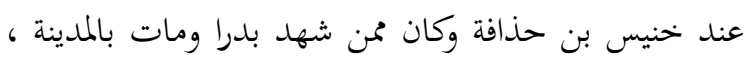

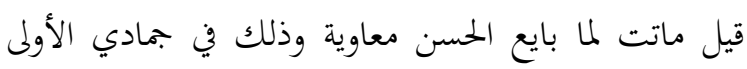

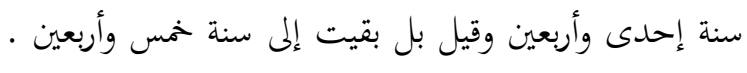
ينظر : الإصابة 581/7 .

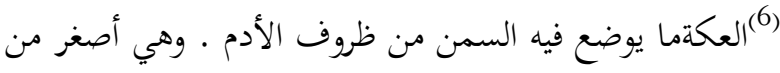

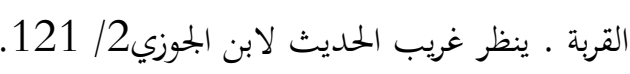

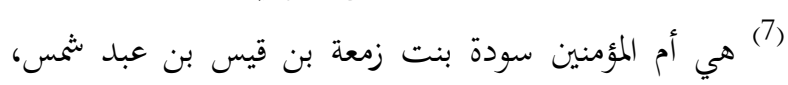

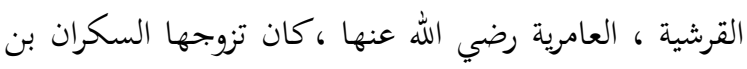

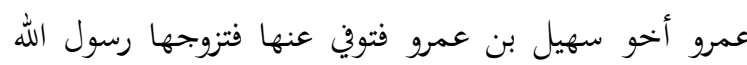

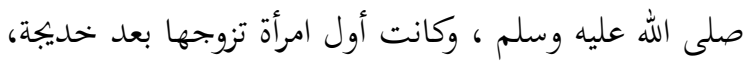

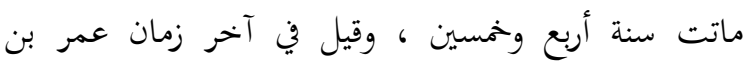

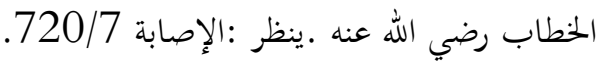

لأن فعولا يشترك فيه الذكر والأنثى .وكثيرا ما جاء فعول للأنثى بغير هاء كعروب وضحوك وشموع • والغيور فعول من الغيرة، وهي الحمية والأنفة، ويقال: رجل مغيار، أي شديد الغيرة، من قوم مغايير ، قال النابغة : مان

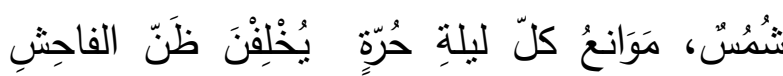
المِغْيارِ - ثانياً : اصطلاحاً :-

هي تغير القلب وهيجان الحفيظة غيرة من المشاركة في الاختصاص أيَّاً كان كراهة مزاحمته ومشاركته فيه، وغالباً ما تكون من أحد الزوجين . (3) قال ابن القيم (ت 756هـ): "والغيرة، نوعان: غيرة من الثيء، وغيرة على الثيء، والغيرة من الثن الثيء هي: كراهة مزاحمته ومشاركته للك في محبوبك.

والغيرة على الثيء هي: شدة حرصك على المحبوب أن يفوز به غيرك دونك، أو يشاركك في هي الفوز به". (4) - (4) 212. 202 (3)

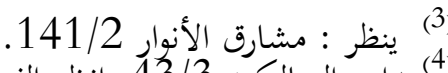
4) مدارج السالكين 43/3 وانظر الفئر الفوائد ص33. 
الريح التي أجد منك ؟ قال: سقتي حفصـة

شربة عسل . فقالت : جرست نحلة العرفط.

فلمـا دار إلـيَّ قلت لـه نحو ذلك، فلمـا دار

إلى صفية قالت له مثل ذللك، فلما دار إلى

حفصة قالت: يا رسول اله ألا أسقيك منه ؟

قال: لا حاجة لي فيه ـ قالت: تقول سودة :

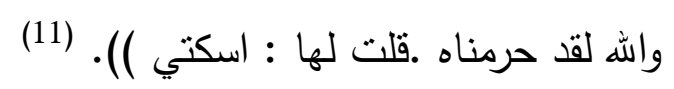

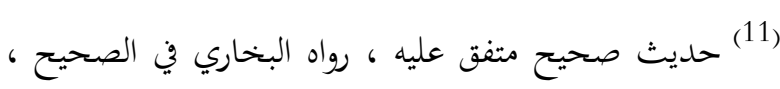

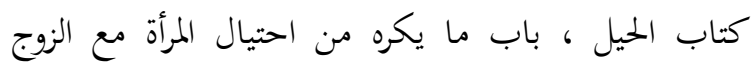

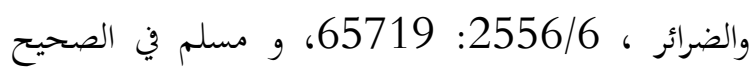

كتاب النكاح ، باب وجوب الكفارة على من حرم امرأته ولم

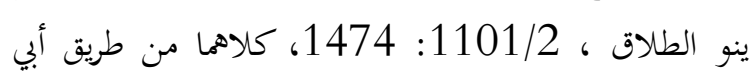

أسامة ، عن هشام ، عن أبيه ، عن عائشة رضي الله عنها.

ه ثعليق : مما في هذا الحديث :

• أنه لا حرج في مرور الرجل وجلوسه وأكله وشربه عند غير ألماثل

ذات النوبة من نسائة ، واستثنى بعض أهل العلم منه أكل

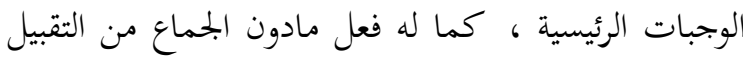

والضم ونحوه. وأن عماد القسمة الليل دون النهار.

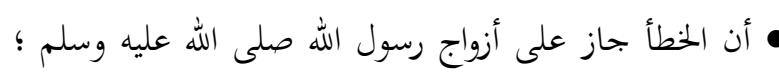

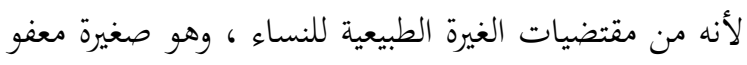

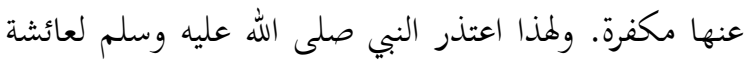

رضي الله عنها عندما غارت وكسرت صحفة ضرتحا بقوله"

غارت أمكم" كما سيأتي في الحديث السادس.

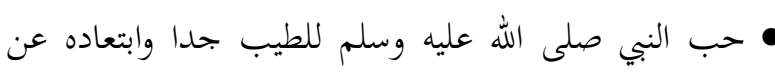

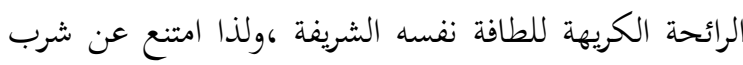

العسل حينما قيل له ما قيل فيه .
مغافير (8) ؟ فإنه سيقول للك : لا ـ فقولي لـ : ما هذه الريح التي أجد منك ؟ فإنه سيقول : مإله للك : سقتني حفصة شربة عسل ـ فقولي لـه

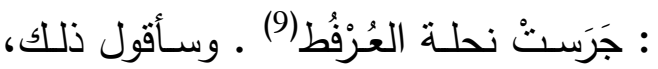

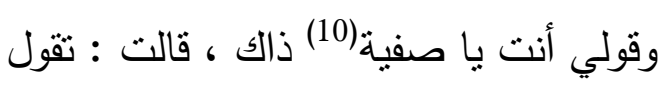

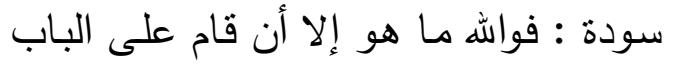

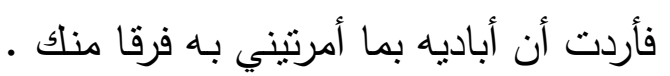
فلما دنا منها قالت له سودة : يا رسول الله أكلت مغافير ؟ قال : لا ـ قالت :فما هذه

(8) شيء كالصمغ ينضحه العرفط، حلو كالناطف ، وله ريح

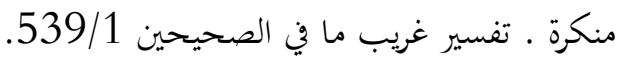

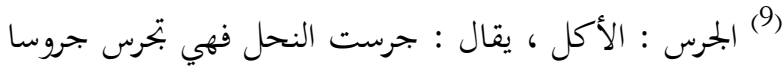

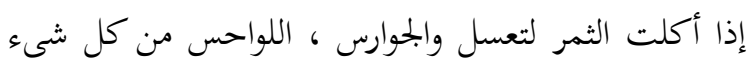

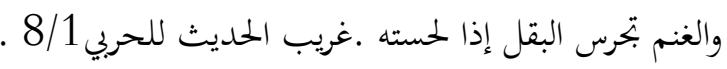

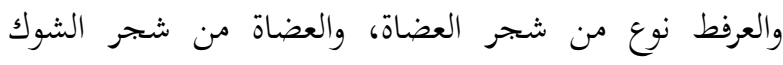

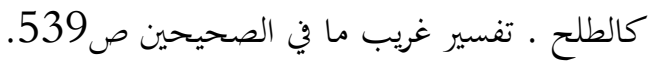

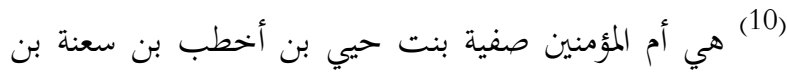

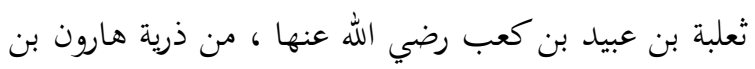

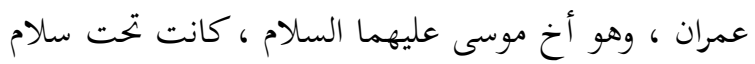

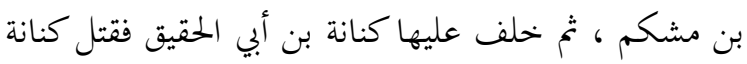

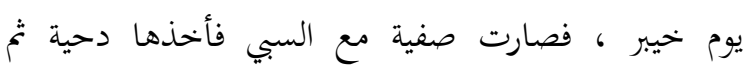

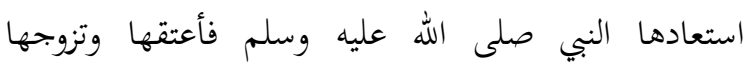
،وكانت رأت قبل ذلك أن القمر وقع في حجرها فذكرت اله

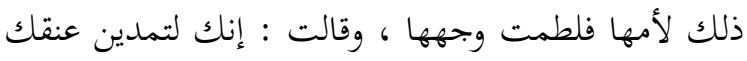

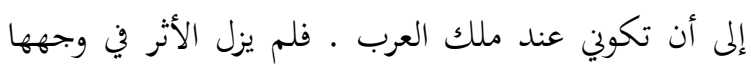

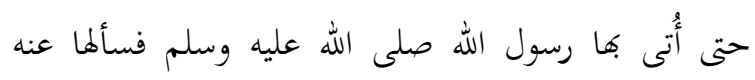

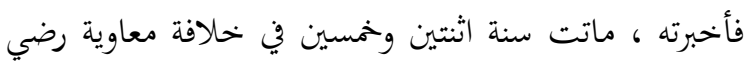
الله عنه. ينظر :الإصابة 738/7. 


$$
\begin{aligned}
& \text { 3. عـن أنس رضـي اله عنـه قـال : () قـال } \\
& \text { عمر : وافقت ربي في ثلاث ، فقلت : يا ليا } \\
& \text { رسـول الله لــو اتخــنـا مـن مقــام إبـراهيم }
\end{aligned}
$$

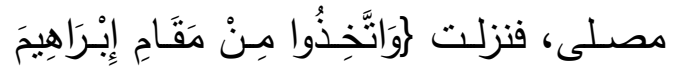

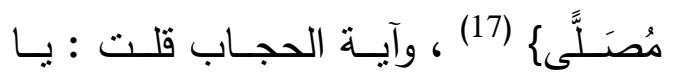

$$
\begin{aligned}
& \text { رسول اله لو أمرت نساءك أن يحتجبن فإنه } \\
& \text { يكلمهن البر والفاجر ، فنزلت آية الحجاب، } \\
& \text { واجتمع نساء النبي صلى الله عليه وسلم في }
\end{aligned}
$$

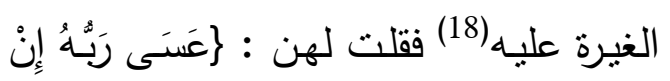

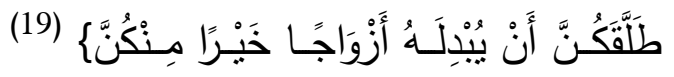

$$
\begin{aligned}
& \text { فنزلت هذه الآية )). (20) }
\end{aligned}
$$

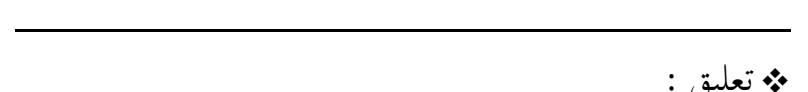

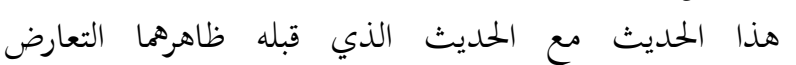

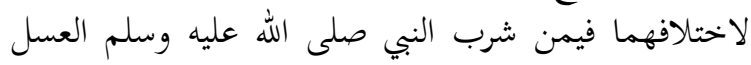

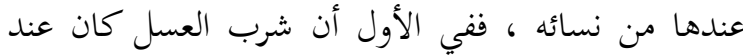

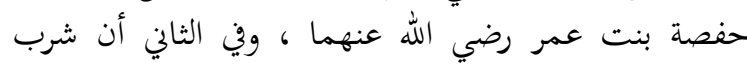
العسل كان عند زينب بنت جحش رضن رضي الله عنها.

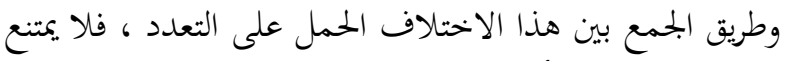

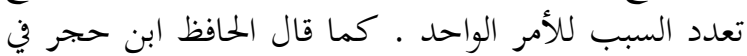
الفتح 376/9.

ولاطلاع على أقوال العلماء في ذلك ينظر : كشف المشكل

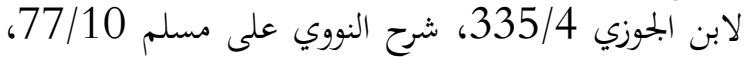

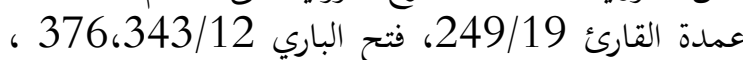

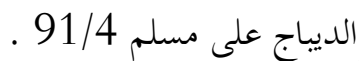

[125 : البقرة 18 يعني الواردة في قصة شربه صلى الله عليه وسلم للعسل

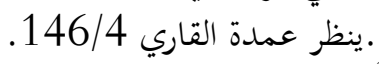

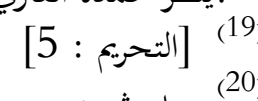

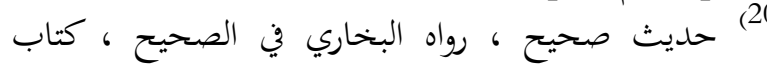

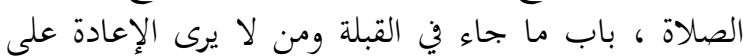

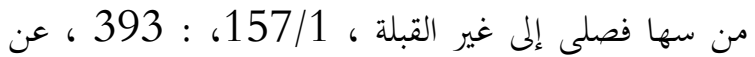

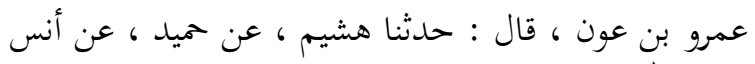

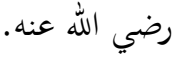

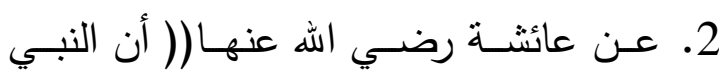

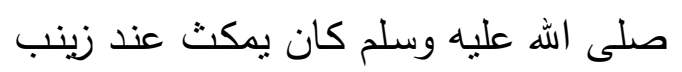

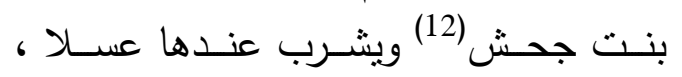
فتواصيت أنا وحفصة أن أيَتُّا دخل عليها

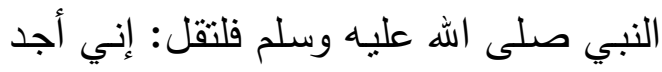

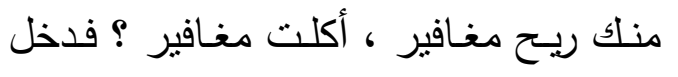

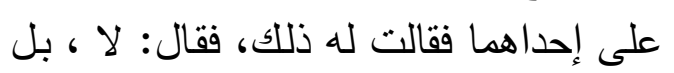

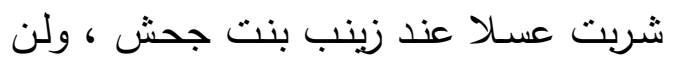

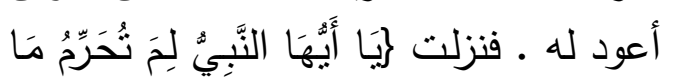

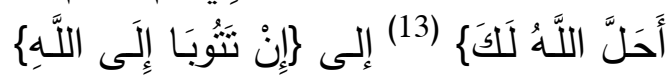

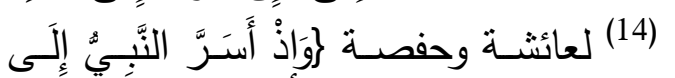

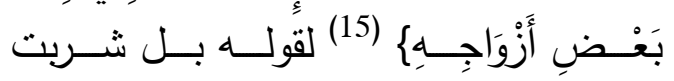

عسلا). (16)

(12) زينب بنت جحش الأسدية رضي الله عنها ، تزوجها النبي

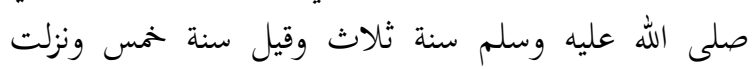

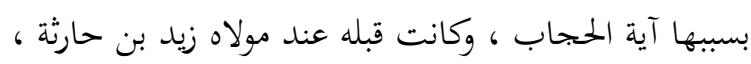

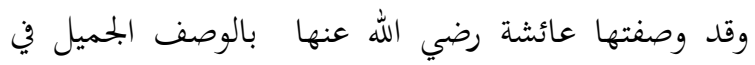

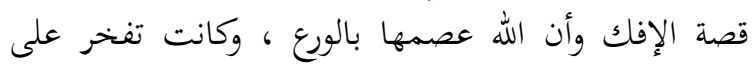

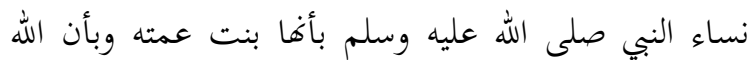

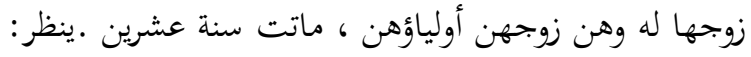
6 الإصابة 667/7. [1: 1 التحرية

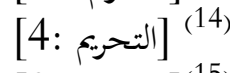
[3] : (15)

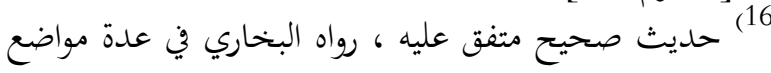

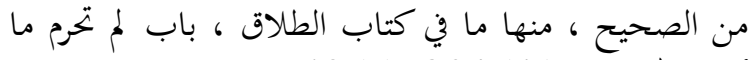

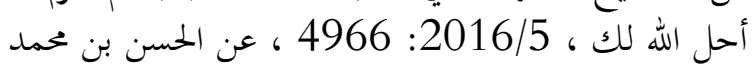

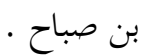

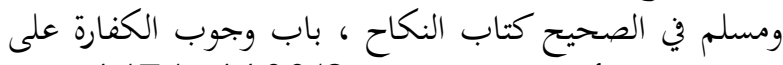

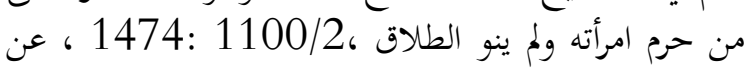
محمد بن حاتم.

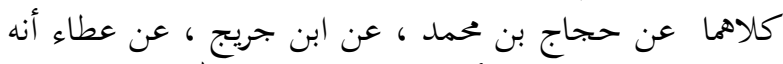
سمع عبيد بن عمير ، أنه سمع عائشة رضي الله آنه عنها. 
فلم تزل به عائشة وحفصة حتى حرمها

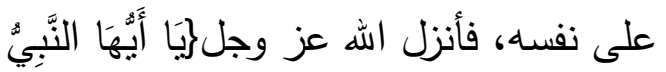

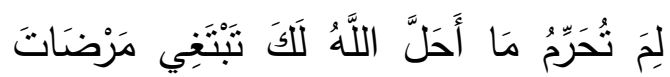

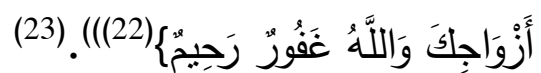

$$
\begin{aligned}
& \text { وألف مثقال ذهبا وعشرين ثوبا لينا وبغلته الدلدل وحماره }
\end{aligned}
$$

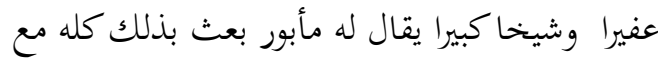

$$
\begin{aligned}
& \text { حاطب بن أبي بلتعة، فعرض حاطب على على مارية الإسلام }
\end{aligned}
$$

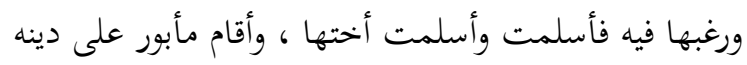

$$
\begin{aligned}
& \text { حتى أسلم بالمدينة بعد في عهد رسول الله صلى الله عليه } \\
& \text { وسلم ، ماتت سنة ست عشرة ـ ينظر : الإصابة 111/8. } \\
& \text { [التحريم: } 1 \text { [ }
\end{aligned}
$$

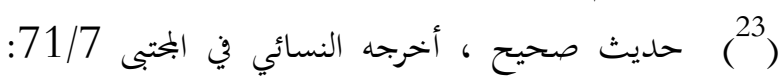

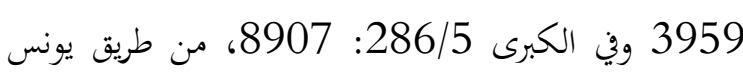

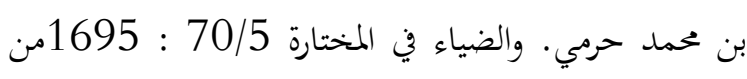

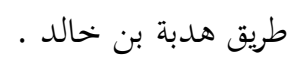$$
\text { كلالهما عن حماد بن سلمة. }
$$

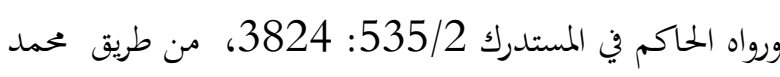$$
\text { بن بكير ، عن سليمان بن المغيرة . }
$$$$
\text { كلاهما عن ثابت ، عن أنس رضي الله عنه. }
$$$$
\text { وصححه على شرط مسلم ، ووافقه الذهبي. }
$$

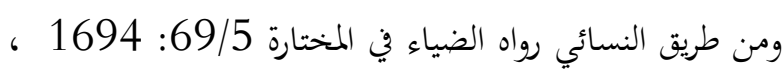

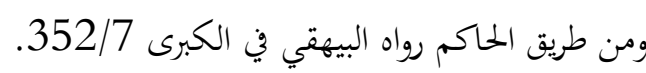
وصحح إسناد النسائي الحافظ في الفتح

$$
\text { أحكامه على سنن النسائي 71/7. }
$$

$$
\text { : خ معليق }
$$

اختُلِف في سبب نزول هذه الآية ، فقيل في قصة العسل ،كما

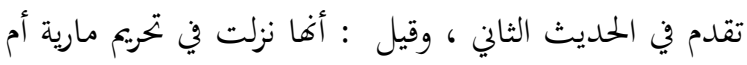

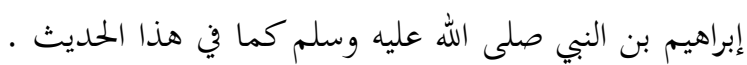

4. عن أنس رضي الله عنه (( أن رسول الله صلى الله عليه وسلم كانت له أمة(21)يطؤها

ورواه أممد في المسند 23/1 : 157، وفي فضائل الصحابة

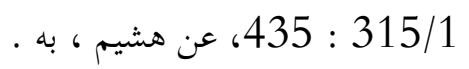

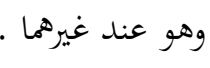

وروى مسلم معناه في حديث طويل من طريق ابن عباس عن عمر رضي الله عنهم في كتاب الطلاق ، باب في الإيلاء

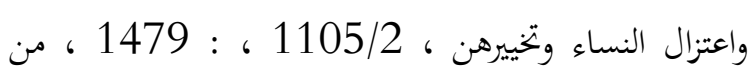

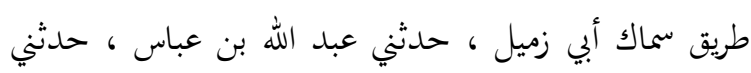

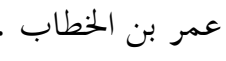

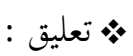

• قول عمر رضي الله عنه "وافقت ربي في ثلاث" ليس في تخصيصه

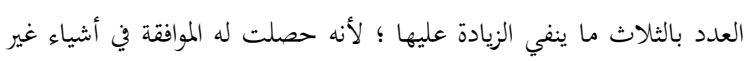

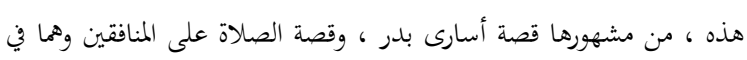

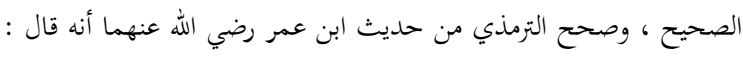

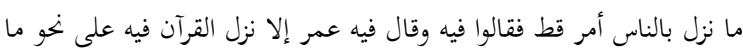

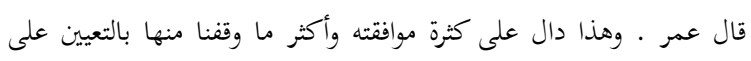

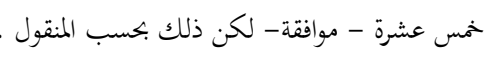
قاله ابن حهر في الفتح -505/1.

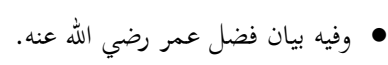

• كما أن في هذا الحديث بيان عظيم خلق البي صلى لفي الله

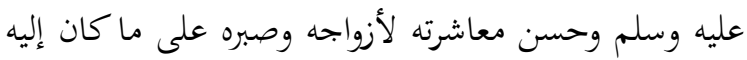

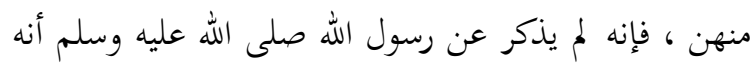

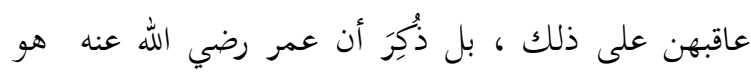

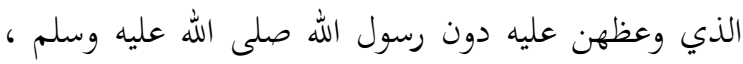

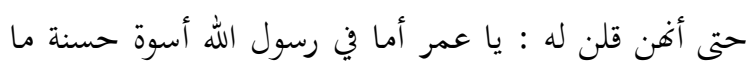
يعظ نساءه حتى تعظهن . (12) هي مارية القبطية ، أم ولد رسول الله صلى الله عليه وسلم

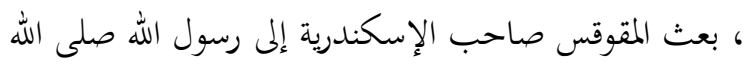

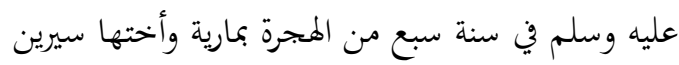




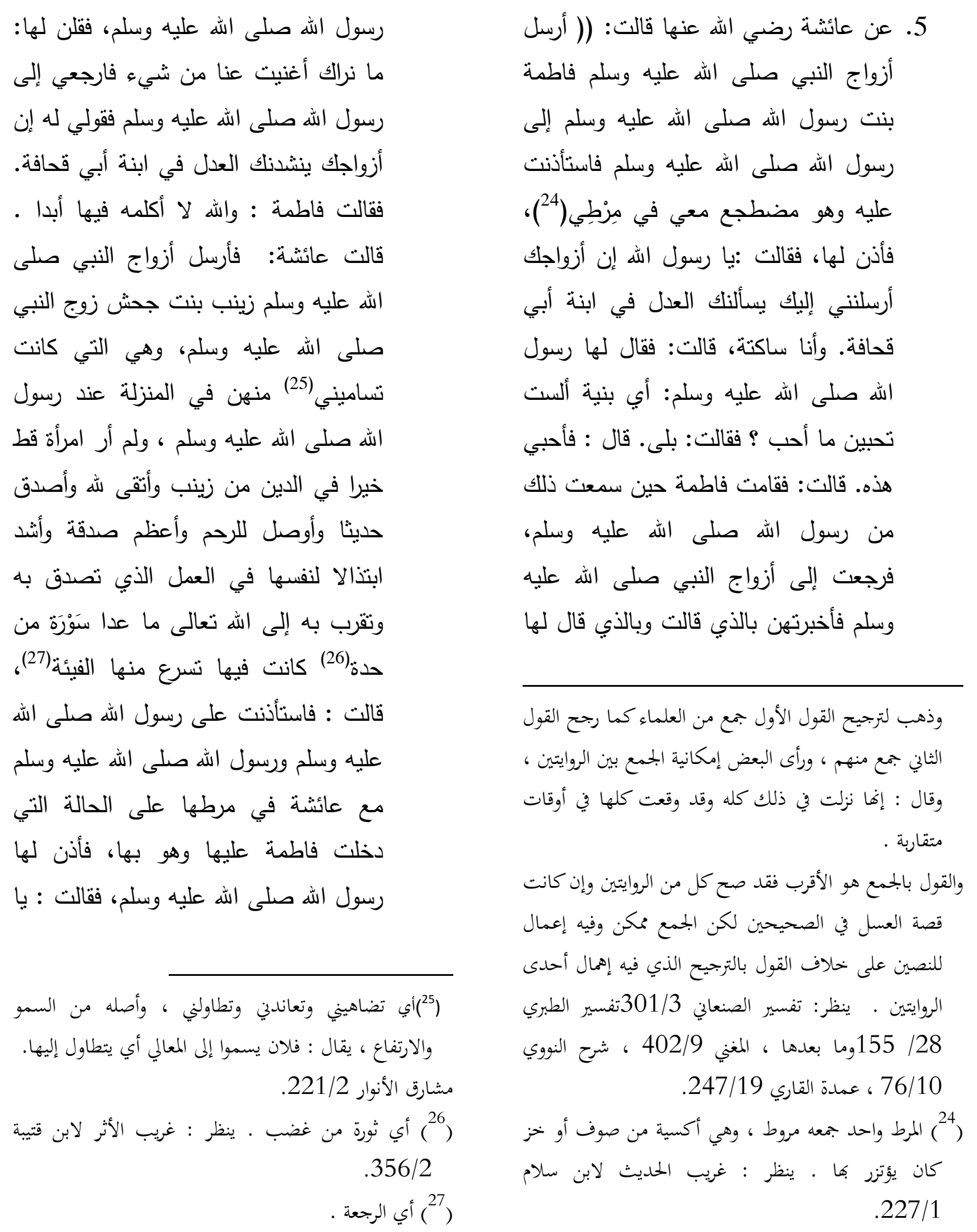


6. عن أنس رضـي الله عنهـ ، قـال :) (كان

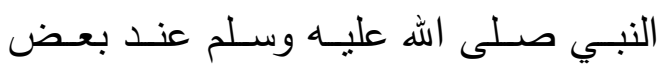

نسائه (31)، فأرسلت إحدى أمهات المؤمنين

(32) بصحفة (33) فيها طعام ، فضربت إحتى أنهات التئين

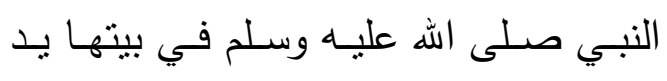

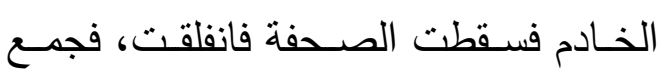

النبي صلى اله عليه وسلم فلق الصحفة ثم الثمان

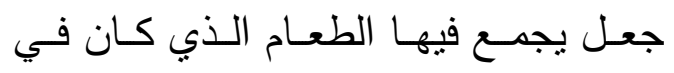

الصحفة، ويقول: غارت أمكم. ثم حبس النس

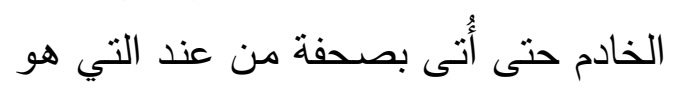

كان يطاف به صلى الله عليه وسلم في مرضه عليهن حتى

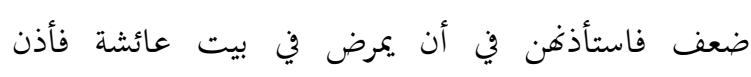

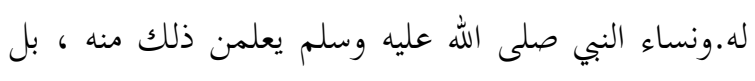

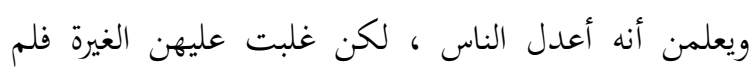

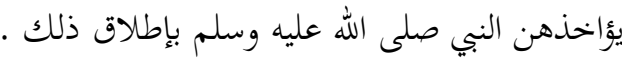

ومما يؤخذ من هذا الحديث جواز الانتقام بالحق فلما انتصرت

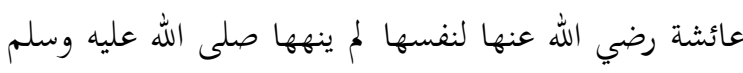

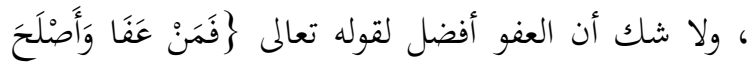

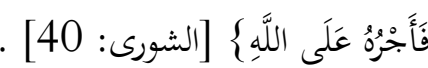

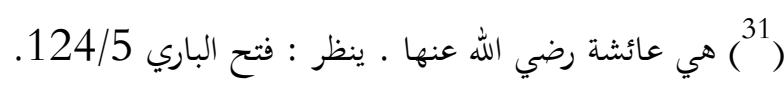

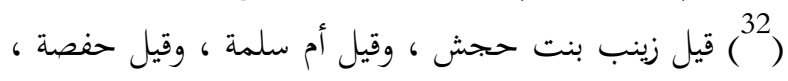

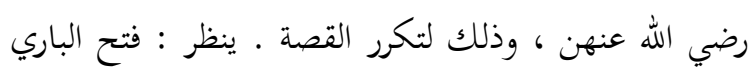

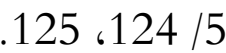

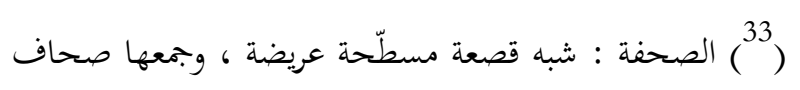

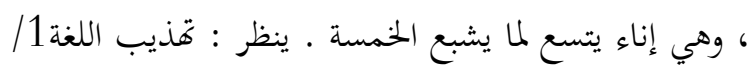

149، مادة صحف إناء بتعل بشع
رسول اله إن أزواجك أرسلنني إليك يسألنك

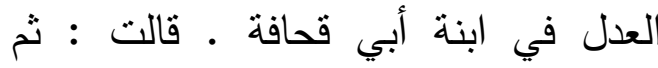

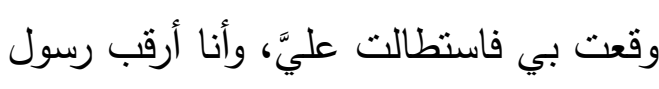
الهه صلى الهه عليه وسلم وأرقب طُرَفَهَه هل

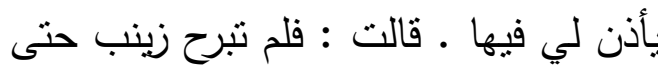
عرفت أن رسول اله صلى اله عليه وسلم لا يكره أن أنتصر ـ قالت : فلما وقعت بها لهال لم أنشبها (28) حين أنحيث(29) عليها ـ قالت: فقال رسول اله صلى الله عليه وسلم، النها وتبسم: إنها ابنة أبي بكر ).

208/1

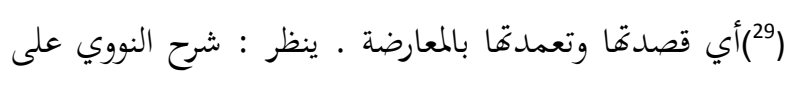
صحيح مسلم 207/15. ( ) (30 حديث صحيح ، رواه مسلم في الصحيح ، كتاب فضائل

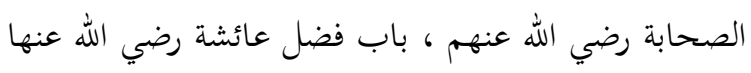

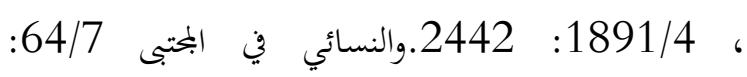

.3944

كالاهما من طريق يعقوب بن إبراهيم بن سعد ، حاثني أبي ،

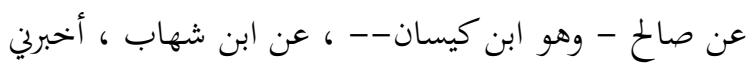

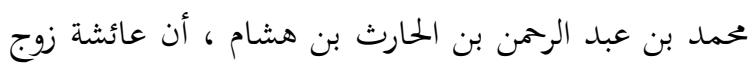

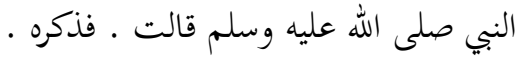

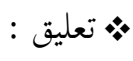

المراد بطلبهن العدل المساواة في محبة القلب لا العدل في الأفعال فإنه كان حاصلا قطعا ، وقد كان صلى الله عليه وسلم

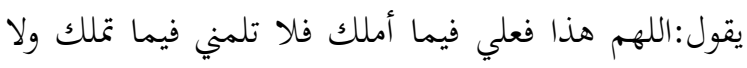

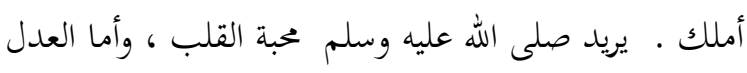
بينهن في النفقة عليهن والقسم بينهن فكان يفعله حتى أنه 


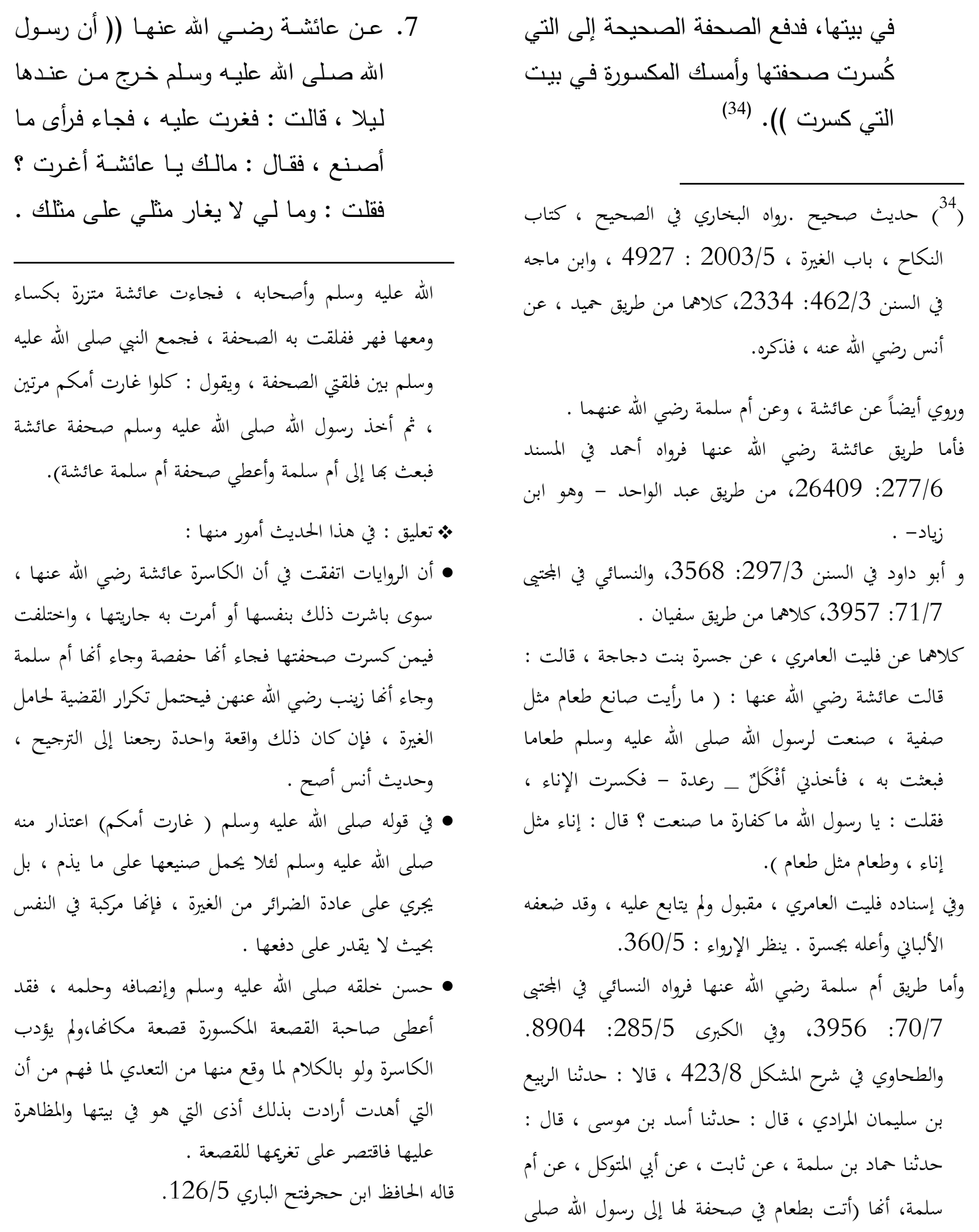




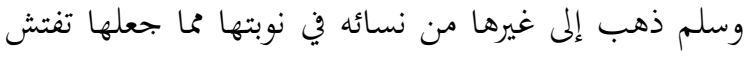

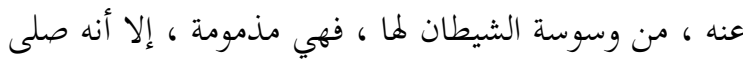

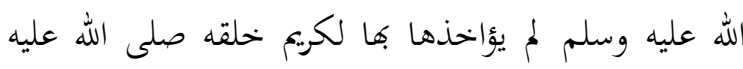
وسلم ، ولكوها مما جبلت عليه النساء من الغيرة الغالبة

عليهن.

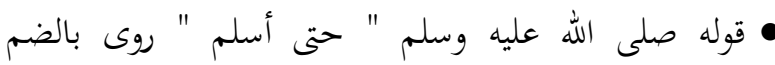
وبالفتح ، فمن رواه بالضم قال : معناه أسلم أنا من شره

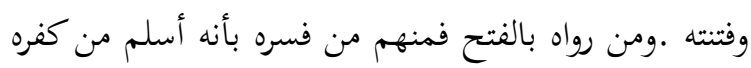

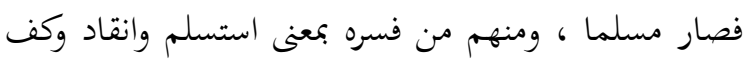

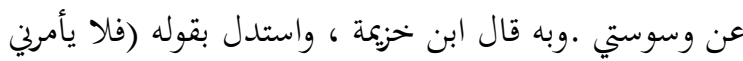
إلا بخير ) قال : ولو كان على الكفر لم يأمر بخير.

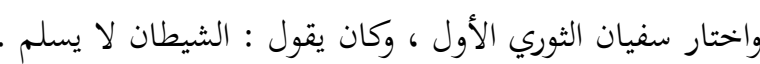
ورجح القاضي عياض رواية الفتح واختارها النووي ، وهو قول

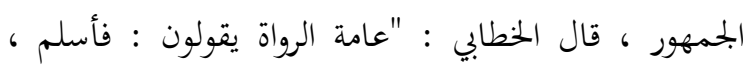

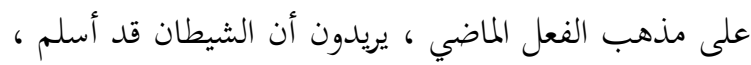

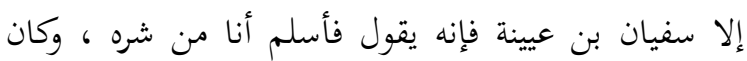
يقول : الشيطان لا يسلم ". ينظر : إصلاح غلط المحدثين

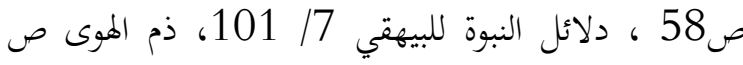
174، شرح النووي 157/17 ، دلاتل النوة لبيهي الباري لابن رجب

واختار ابن تيمية التفسير الثاني لرواية الفتح ، وقال : " والمراد في أصح القولين استسلم وانقاد لي ، ومن قال حتى أسلم أنا

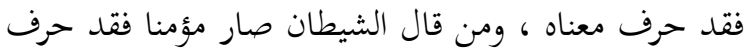
لفظه" . منهاج السنة 271/8.

وقال أيضاً : " وكان ابن عيينة يرويه فأسلمُ بالضم ، ويقول :

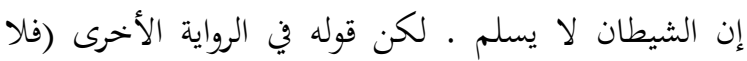

فقال رسول الله صلى الله عليه وسلم : أقد جاءك شيطانك ! قالت : يـا رسـول الله أو معي شيطان ؟ قال : نعم . قلت : ومع كل

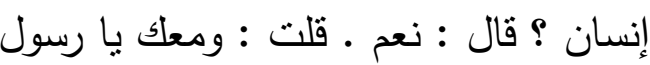

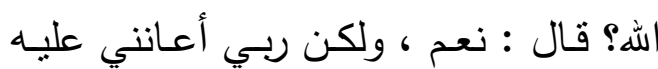
حتى أسلم (). (35)

( $)^{35}$ حديث صحيح ، رواه مسلم في الصحيح ، كتاب صفة القيامة والجنة والنار ، باب تحريث الشيطان وبعثه سراياه

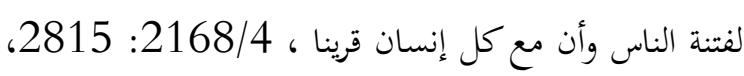

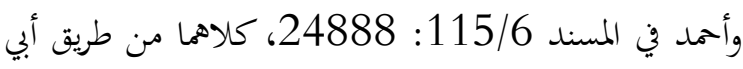
صخر - وهو حميد بن زياد - ، عن ابن قسيط - هو يزيد بن عبد الله بن قسيط - ، حدثه أن عروة حدثه ، أن عائشة زوج النبي صلى الله عليه وسلم حدثته ، به . ولآخره شاهد من حديث ابن مسعود رضي الله عنه ، رواه

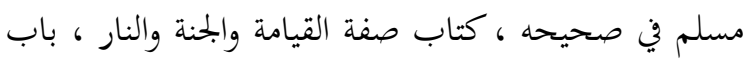
تريش الشيطان وبعثه سراياه لفتنة الناس وأن مع كل إنسان

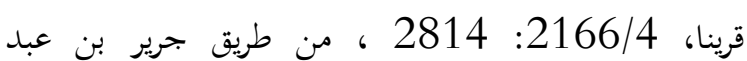

وأحمد في لمنسند، 401/1: 3802 ، من طريق سفيان.

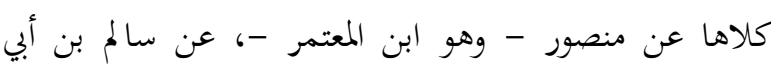

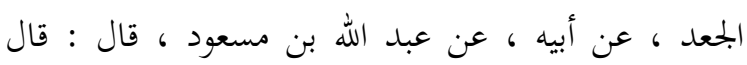

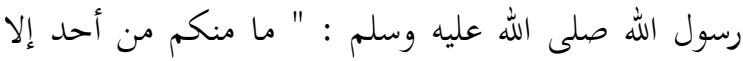

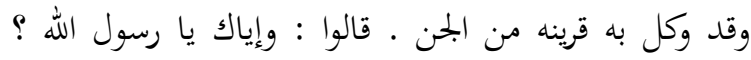
قال : وإياي ، إلا أن الله أعاني عليه فأسلم ، فلا يأمرين إلا فياك

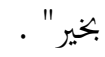
ثر تعليق : محا في هذا الحديث:

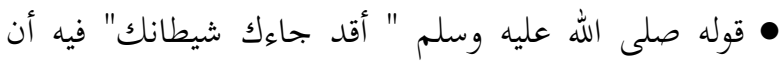

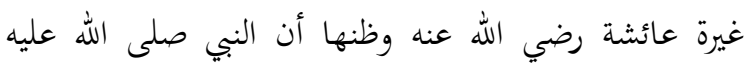




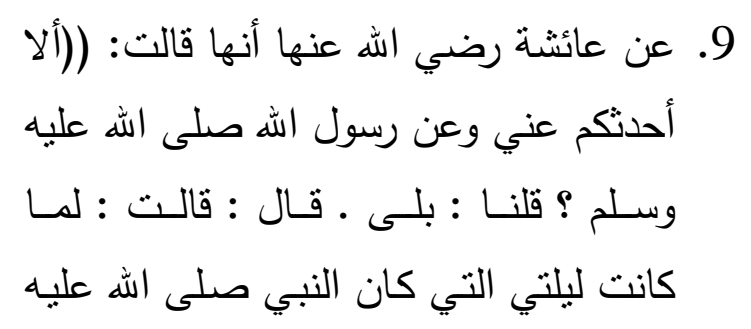

الركوع ؟ قال : لا ـ قلت : فما تتبع في ذلك ؟ قال : أما

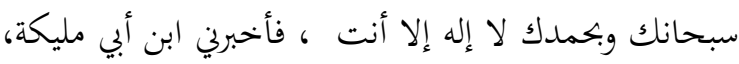
عن عائشة قالت "، فذكره .

ومن طريق عبد الرزاق رواه مسلم في الصحيح ، كتاب الصلاة ، فذكان ،

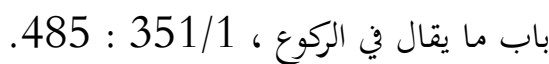

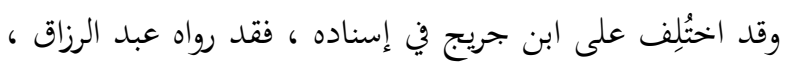
عن ابن جريجج ، عن عطاء ، عن ابن أبي مليكة كما تقدم.

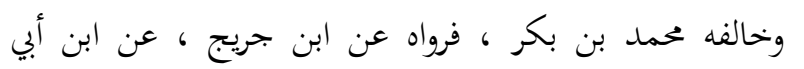

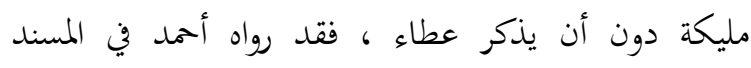

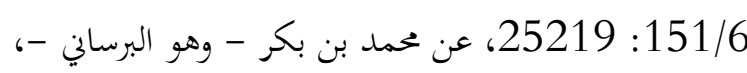

وقد توبع عبد الرزاق فيه ، تابعه حجاج بن محمد المصيصي ، فئل

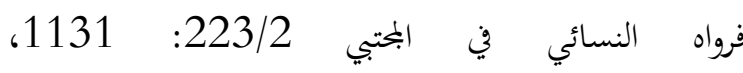

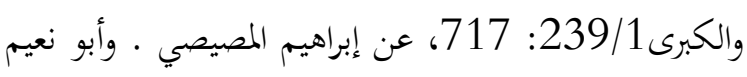
في المستخرج 99/2: 1079، من طريق عبد الله بن محمد بن تميم . كلاهما عن حجاج ، عن ابن جريج ، عن عطاء ،

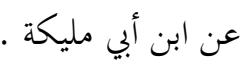
وابن جريج سمع من عطاء ومن ابن أبي مليكة ، وقد روى له له

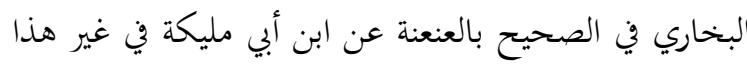

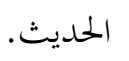

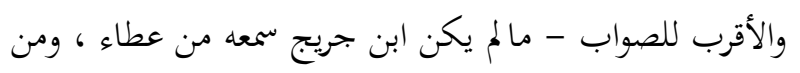

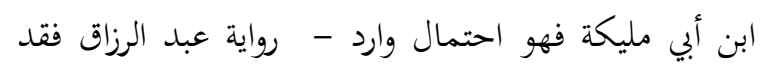

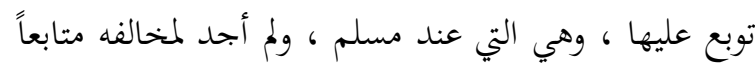
وإن كان ثقة .

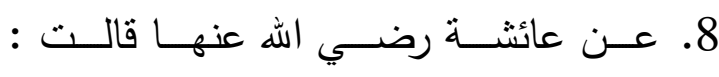

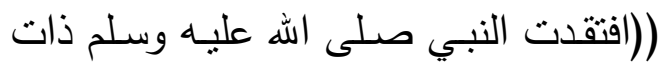
ليلة ، فظنتت أنه ذهب إلى بعض نسائه ، فجست ثم رجعت ، فإذا هو راكع وساجد

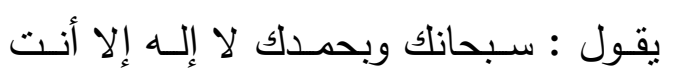
قالت : قلت : بأبي أنت وأمي إني لفي شأن وإنك لفي آخر (). : (36)

يأمرني إلا بخير) دل على أنه لم يبق يأمره بالشر وهذا

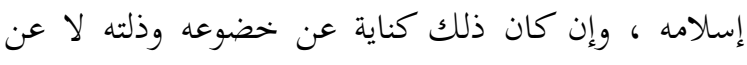

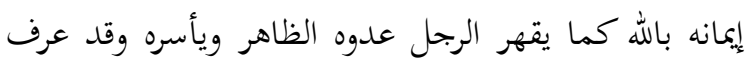
العدو المقهور أن ذلك القاهر يعرف ما يشير به عليه من الهن

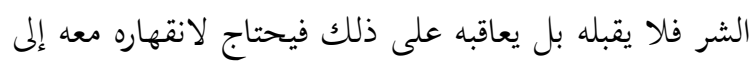

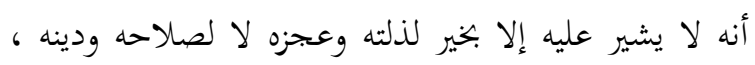
ولهذا قال صلى الله عليه وسلم ( إلا أن الله أعاني عليه فلا لاحتيه ودينه يأمرني إلا بخير ) " .بحموع الفتاوى 523/17. وما ذهب إليه ابن تيمية جمع حسن. ( ) (36) حديث صحيح ، رواه عبد الرزاق في المصنف 160/2:

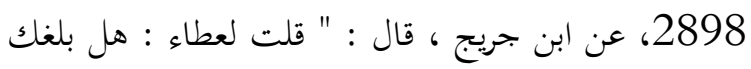

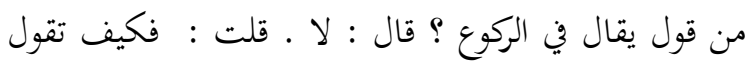

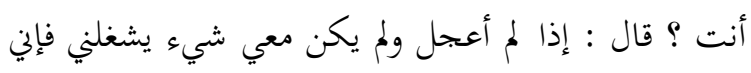

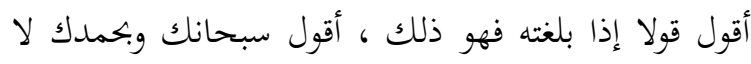

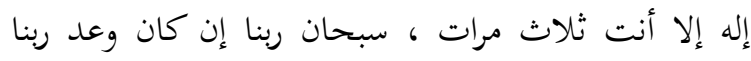

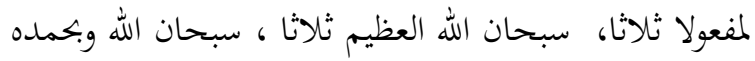
ثلاث مرات ، سبحان الملك القدوس ثلاث مرات ، سبوح قدوس رب الملائكة والروح سبقت رمة ربح ربي غضبه ثلاث

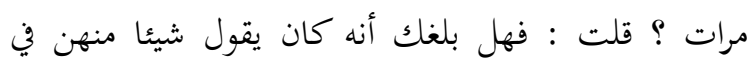


؟ قالت: مهما يكتم الناس يعلمه الله ـ قال :

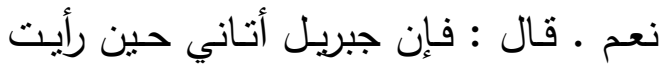

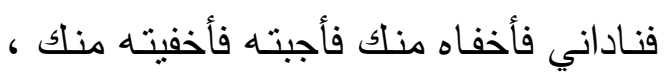

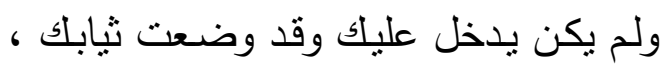

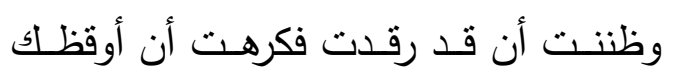

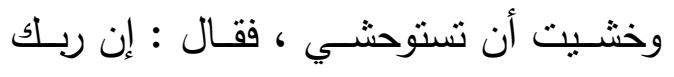

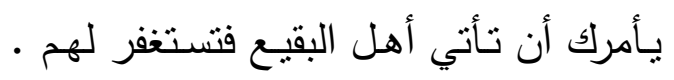

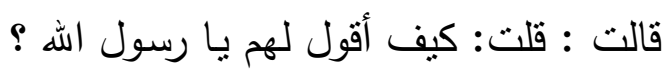

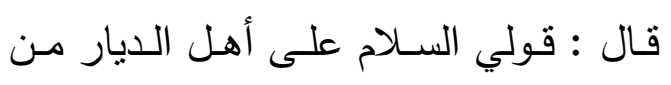

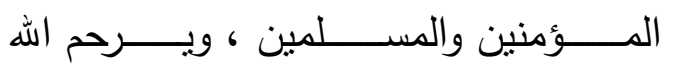

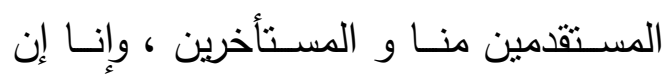

شاء الله بكم للاحقون )). (40)

(40) حديث صحيح ، رواه مسلم في الصحيح ، كتاب

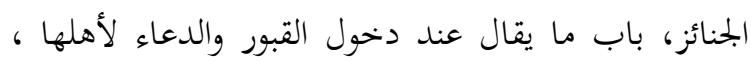

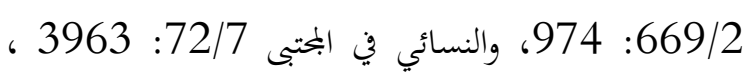

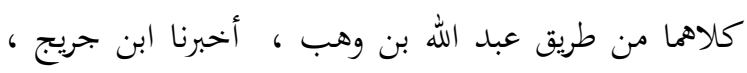

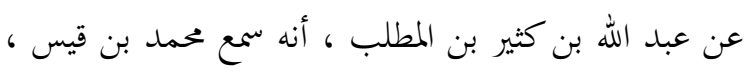

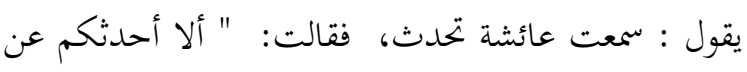

$$
\text { النبي صلى الله عليه وسلم وعني " ـ فذكره . }
$$

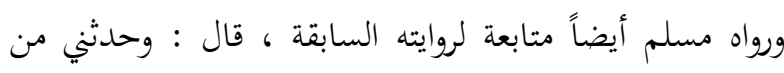

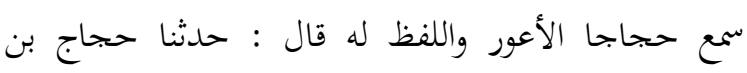

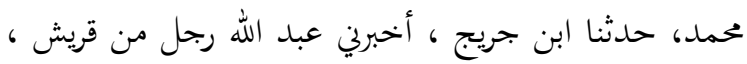

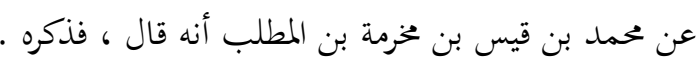

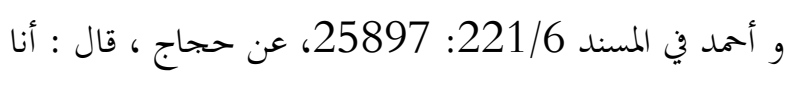

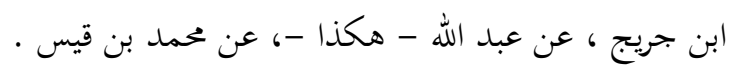

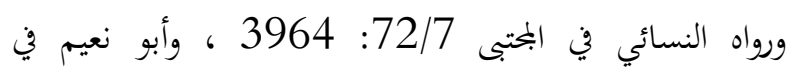

المستخرج 54/3: 2188، كلاهما من طريق يوسف بن
وسلم فيها عندي انقلب فوضع رداءه وخلع

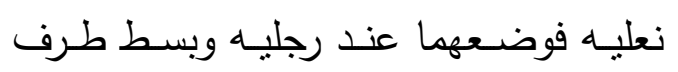

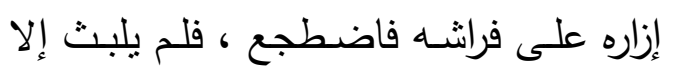

ريثما ظن أن قد رقدت ، فأخذ رداءه رويدا

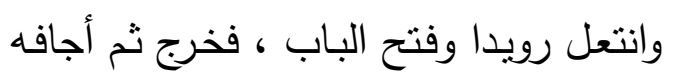

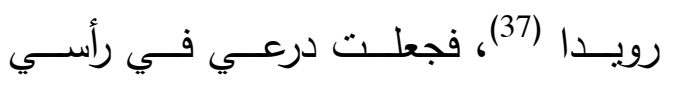

واختمرت وتقنعت إزاري ، ثم انطلقت على

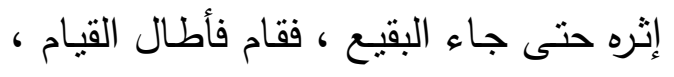

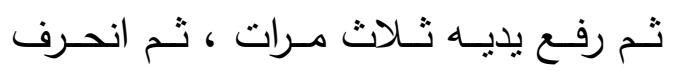

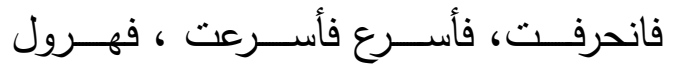

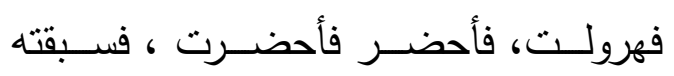

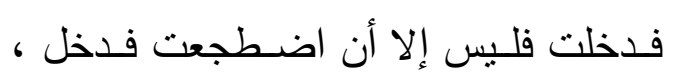

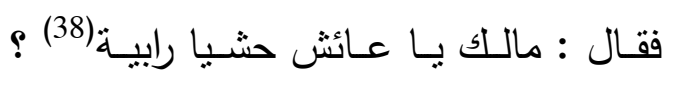

قالت : قلت : لا شيء ـ قـال : لتخبريني

أو ليخبرني اللطيف الخبير ـ قالت : قلت :

يا رسول الله بأبي أنت وأمي فأخبرته ـ قال

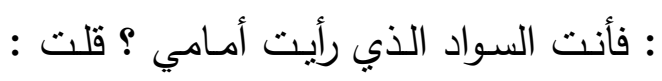

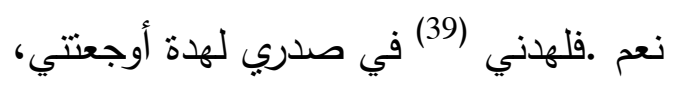

ثم قال:أظننت أن يحيف الله عليك ورسوله

أي أغلقه ، وإنما فعل ذلك صلى الله عليه وسلم في خفية

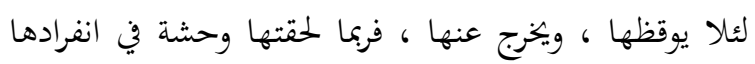

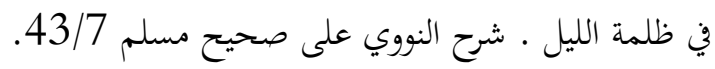

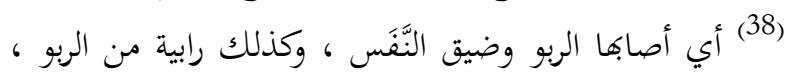

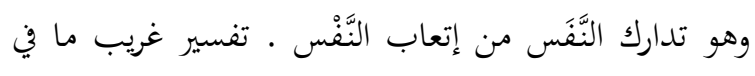

الصحيحين ص 558.

399 أي دفع في صدري . مشارق الأنوار $553 / 1$. 
10. عـن عائثــة رضــي الله عنهـا، قالـت :

(كان رسول اله صـلى الله عليه وسـلم إذا

خرج اقرع بين نسائه ، فطارت القرعة على الى الئ

عائشة وحفصة فخرجتا معه جميعا ، وكان

رسـول الله صـلـى الله عليـهـ وســلم إذا كـان

بالليل سار مع عائشة يتحدث معها ، فقالت حفصـة لعائثــة :ألا تـركبين الليـــة بعيـري

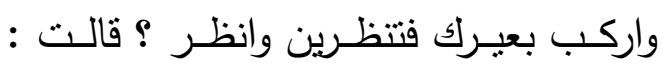

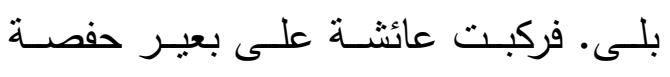

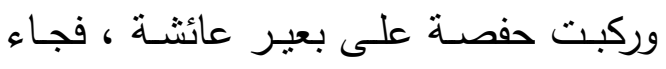

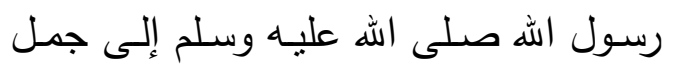

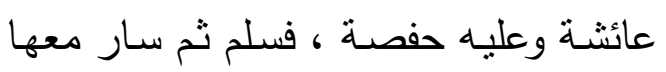

حتى نزلوا ، فافتقدته عائشـة فغارت ، فلما

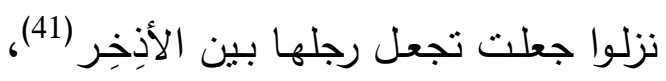

وتقول : يـا رب سـلط علي عقربـا أو حيـة

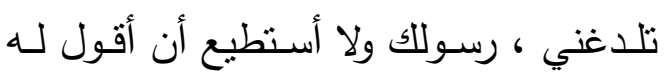

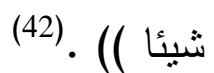

كراهة أن يوقظها وخشية أن تستوحش، فسبحان من وهبه كمال البشرية وأعلى مراتب الإنسانية.

( ) هي حشيشة طيبة الريح .غريب الحديث للحربي الانسانية .535/2

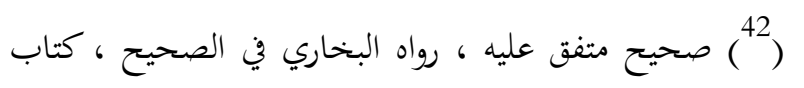

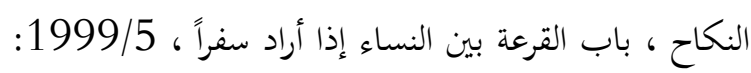

.4913
سعيد المصيصي، عن حجاج ، عن ابن جريج ، عن ابن أبي

مليكة ، عن محمد بن قيس.

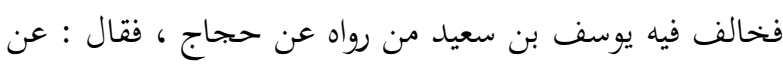
ابن جريج ، عن ابن أبي مليكة ، عن محمد بن قيس.

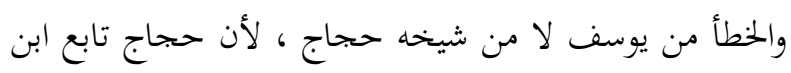
وهب في روايته المتقدمة عند مسلم ، والنسائي.

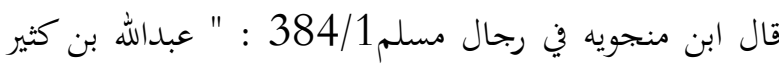

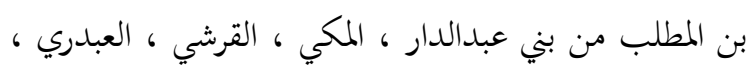

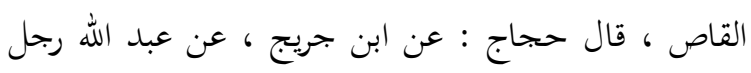

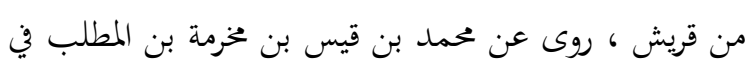

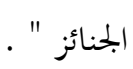

وأكد ذلك العطار في غرر الفوائد ص146 ، قال : " إلا أن

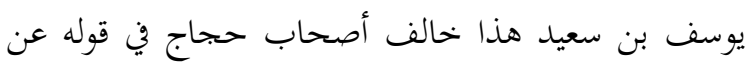

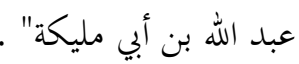

وقال الذهبي : ما اختلفا فيه - يعني ابن وهب وحجاجاً لـ - وإنما ابن مسلم - يعني يوسف بن سعيد - زاد من عنده إيضاحا بكسب ظنه ، فقال بعد عبد الله : ابن أبي مليكة .السير

.322/5

• ثعليق: في هذا الحديث أمور منها :

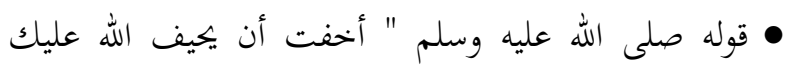

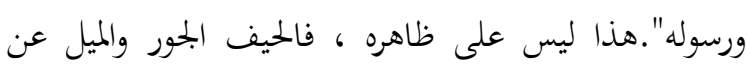

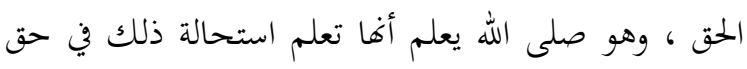

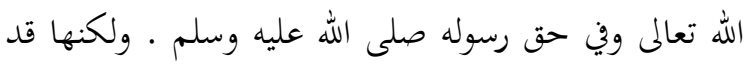

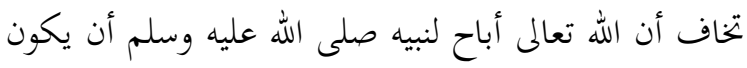

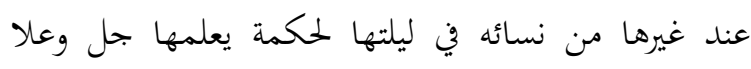
فلما كان الحيف بمعنى الميل أقيم مقامه.

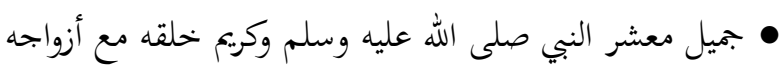

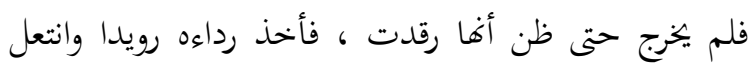
رويدا وفتح الباب رويدا، فخرج ثم أجافه رويدا ، كل ذلن ذلك رداءه روبد وانعل 
خـف ومتــاع صـفية كـان فيـه ثقل فبطـا بالركب ، فحولنا متاعك على بعيرها وحولنا متاعها على بعيرك ـ قلت : ألست تعزعم أنـك رسـول الله! قالـت : فتبسـم رسـول الله صلى الله عليه وسلم ، فقال : أفي شك أنت

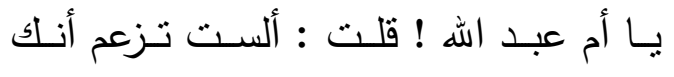
رسول الله ، فهلا عدلت ! فسمعني أبو بكر

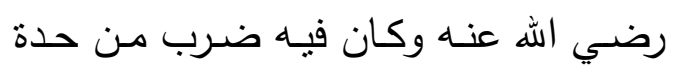

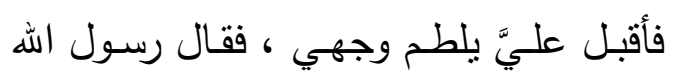

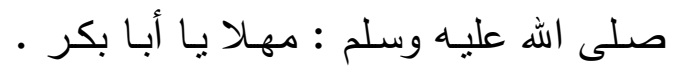

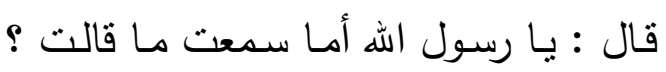
قال : إن الغيرى لا تبصر أسفل الوادي من

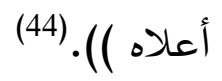

(44) إسناده ضعيف ، وقد رواه أبو يعلى في المسند ، 129/8:

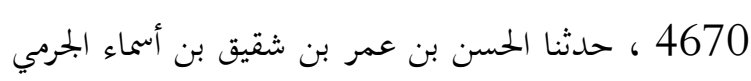
البصري ، حدثنا سلمة بن الفضل ، عن محمد بن إسحاق ،

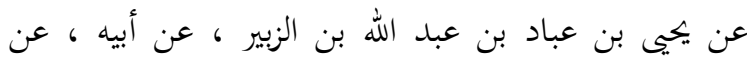
عائشة رضي الله عنها ، فذكره .

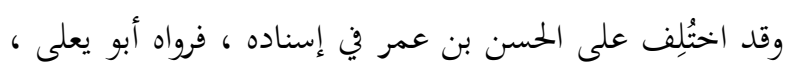

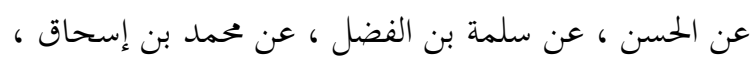

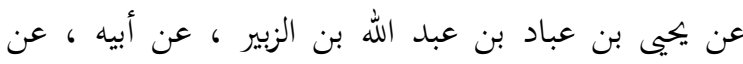

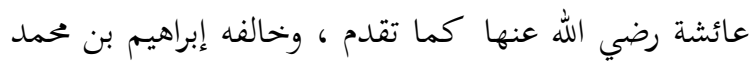

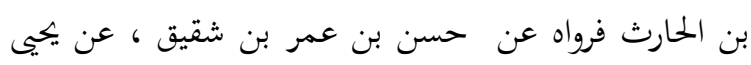

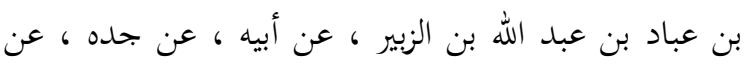

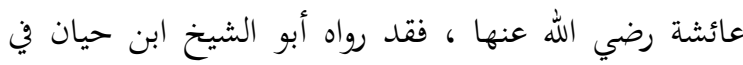
أمثال الحديث ص95 : 65، عن إبراهيم بن محمد ، به . .

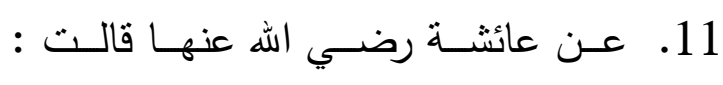

(خرجـت مـع رسـول الله صـلـى الله عليـهـ

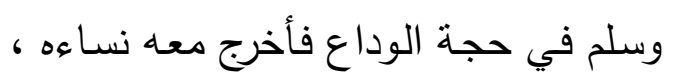

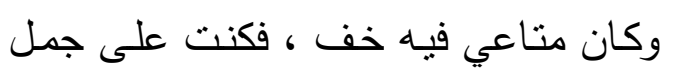
ناج(43)، وكان متاع صفية بنت حيـ فيه فيه ، ققل وكانت على جمل بطيء فتباطأنسا

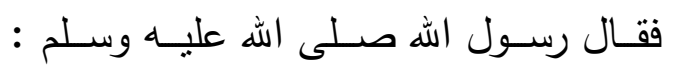
حولوا مناع عائشة على جمل صفية وحولوا

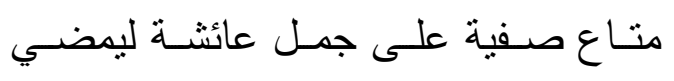
الركب ـ فلما رأيت ذلك قلت : يا لعباد الله

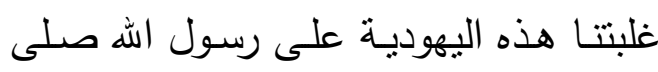
الله عليه وسلم • فقال النبي صلى الله عليه وسـلم : يـا أم عبد الله إن متاعلك كان فيهـ

ومسلم في الصحيح ، كتاب فضائل الصحابة رضي الله عنهم ،

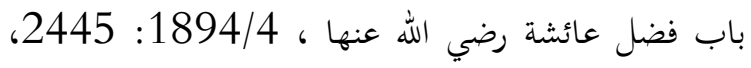

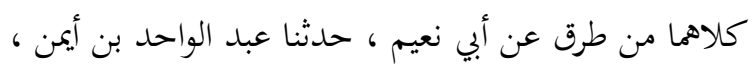

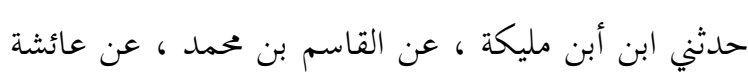
رضي الله عنها. وهو عند غيرهما . رضي الماك.

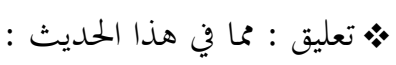

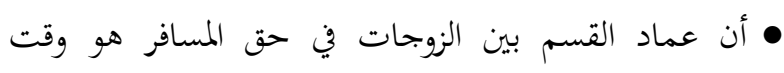

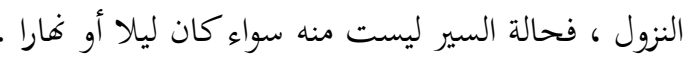

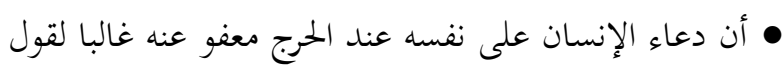

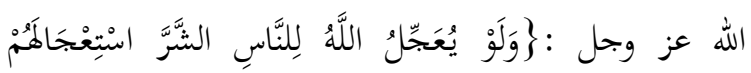

بالِنْيْرِ

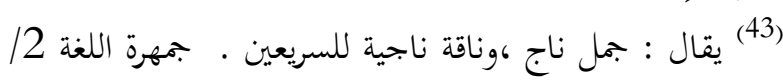
1046 


$$
\begin{aligned}
& \text { ورواه الطبراني في الكبير 71/24: } 188 \text { ، و وي الأوسط3/ } \\
& \text { 99: 2609، من طريق أبي عمر الضرير . } \\
& \text { 12. عن عائشة رضي الله عنها (( أنه اعتل } \\
& \text { بعير لصفية بنت حيي وعند زينب فضل } \\
& \text { خمستُهم عن حماد - وهو ابن سلمة-، عن ثابت - وهو } \\
& \text { البناني-، عن سمية، عن عائشة رضي الله عنها ـ فذكره . } \\
& \text { وعند أحمد في رواية عفان "شميسة" مكان "سمية". } \\
& \text { ورواه أحمد في المسند337/6 : } 26908 \text { ، عن عبد الرزاق ، }
\end{aligned}
$$

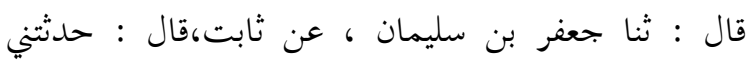

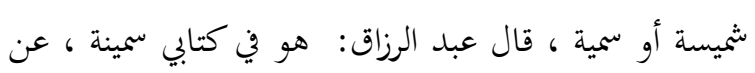

$$
\begin{aligned}
& \text { صفية رضي الله عنها ، فذكره بأطول من هذا. } \\
& \text { وقد اختُلِفف على ثابت في إسناده ففي طريق حماد قال عن } \\
& \text { عائشة ، وفي طريق عبد الرزاق قال عن صفية. } \\
& \text { والصواب من قال عن عائشة رضي الله عنها ، فحماد بن سلمة }
\end{aligned}
$$

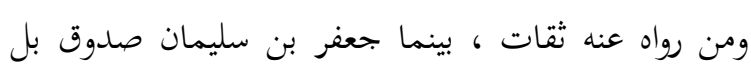

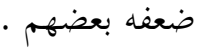

$$
\begin{aligned}
& \text { وقد توبع ثابت في روايته لطريق عائشة رضي الله عنها تابعه }
\end{aligned}
$$

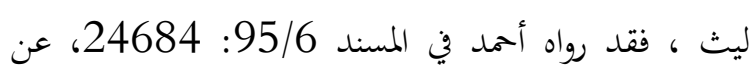

$$
\begin{aligned}
& \text { عفان ، عن حماد ، عن ليث وثابت ، عن سمية ، عن عائشة ، رونة } \\
& \text { رضي الله عنها بمعناه. } \\
& \text { وأورد الهيثمي طريق عبد الرزاق في بحمع الزوائد 4/ 321، }
\end{aligned}
$$

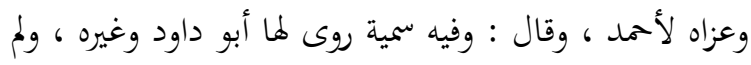

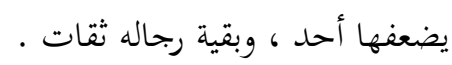

$$
\begin{aligned}
& \text { وأورده بطريقيه ابن حجر في إتحاف المهرة 994/16، وعزاه } \\
& \text { لأحمد. }
\end{aligned}
$$

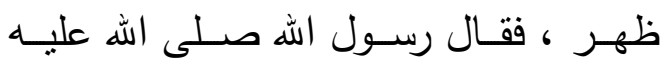

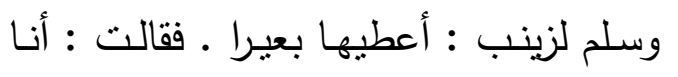

$$
\begin{aligned}
& \text { أعطي تلك اليهوديـة ـ فغضـب رسـول الله }
\end{aligned}
$$

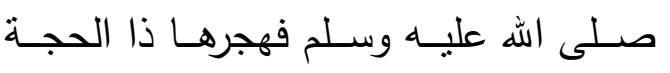

$$
\begin{aligned}
& \text { والمحرم وبعض صفر )). (45) } \\
& \text { وهذا لا يضر فإن عباداً سمع من أبيه ومن عائشة ، وسمع أبوه }
\end{aligned}
$$

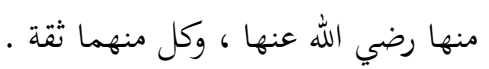

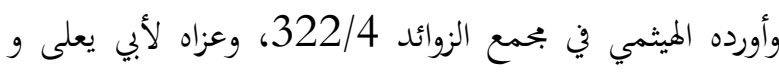

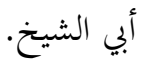

$$
\begin{aligned}
& \text { وفي إسناده سلمة بن الفضل ضعيف ، قال البخاري عنده }
\end{aligned}
$$

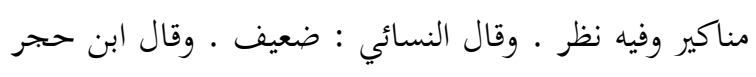

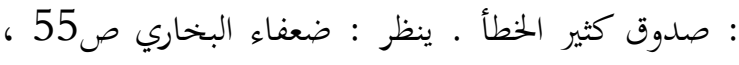

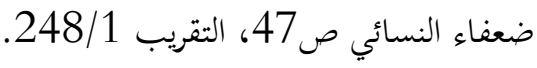

$$
\begin{aligned}
& \text { وفيه أيضاً عنعنة ابن إسحاق وهو مشهور بالتدليس . }
\end{aligned}
$$

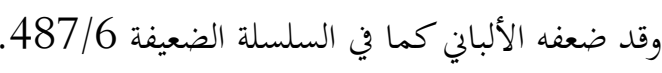

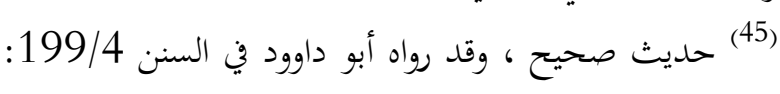

$$
\begin{aligned}
& \text { 4602، عن موسى بن إسماعيل - هو التبوذكي-. } \\
& \text { ورواه أممد في المسند 145/6: 25165، عن يزيد - هو ابن } \\
& \text { هارون - . } \\
& \text { ورواه إسحاق بن راهويه في المسند 779/3: 1408، عن }
\end{aligned}
$$

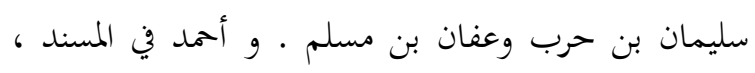

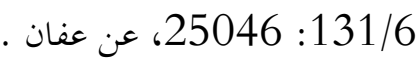


فترك الاعتكاف حتى أفطر من رمضان ثم

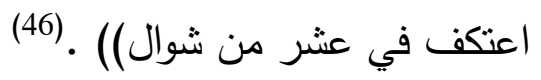

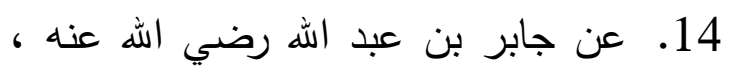

قال: (( دخل أبو بكر يستأذن على رسول

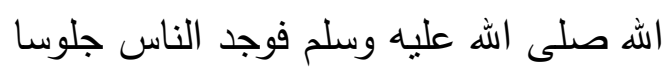

ببابه لم يؤذن لأحد منهم، قال : فأذن لأبي

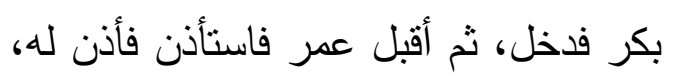

فوجد النبي صلى اله عليه وسلم جالسا

حوله نساؤه واجما ساكتا، قال: فقال: لأقولن

$$
\begin{aligned}
& \text { (2224) حديث صحيح ، رواه ابن خزيمة في صحيحه ، 345/3: }
\end{aligned}
$$

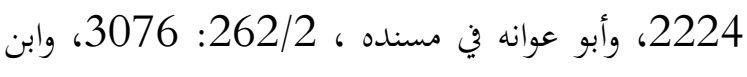

$$
\begin{aligned}
& \text { حبان في صحيحه ، 425/8: 3667، جمعيهم من طريق }
\end{aligned}
$$

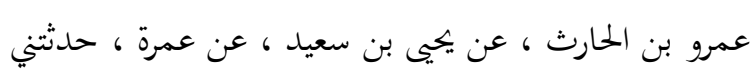

$$
\begin{aligned}
& \text { عائشة رضي الله عنها ، فذكره . }
\end{aligned}
$$

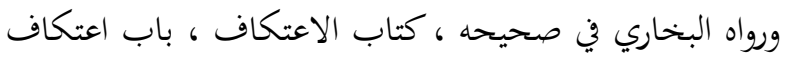

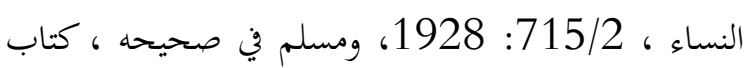

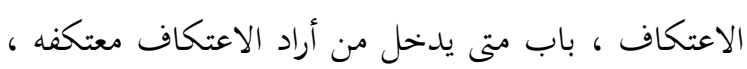

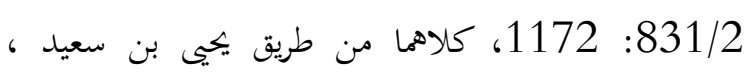

$$
\begin{aligned}
& \text { بنحوه، دون قوله " وكانت امرأة غيورا". }
\end{aligned}
$$

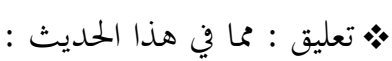

$$
\begin{aligned}
& \text { • جواز اعتكاف النساء ؛ لأنه عليه السلام أذن لعائشة } \\
& \text { وحفصة في ذلك . } \\
& \text { • لا بد من إذن الزوج إذا أرادت المرأة الاعتكاف ، والأفضل }
\end{aligned}
$$

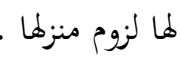

$$
\begin{aligned}
& \text { • جواز اتخاذ مكان خاص في المسجد للمعتكف وضرب } \\
& \text { الأخبئة فيه. }
\end{aligned}
$$

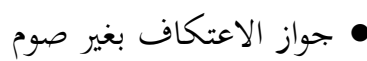

$$
\begin{aligned}
& \text { • استحباب قضاء النوافل المعتادة إذا فاتت لعذر . ل }
\end{aligned}
$$

13. عن عائثة رضي الله عنها (( أن النبي

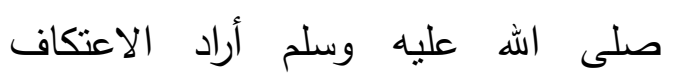

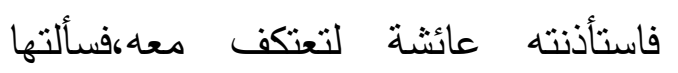
حفصة تستأذن لها لتعتكف معه، فلم ارأته زينب ضربت معهن وكانت امرأة غيورا، فرأى رسول الله صلى الله عليه وسلم أخبيتهن، فقال: ما هذا البر يردن بهذا!؟

قلت : سمية وشميسة واحدة على ما يظهر ، وسبب الاختلاف

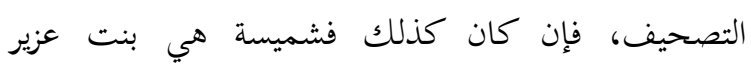

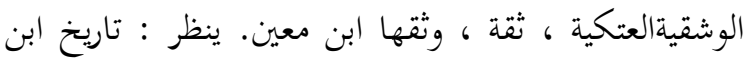

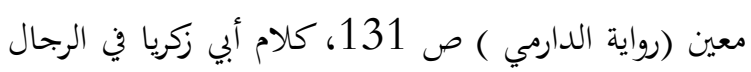
ص105، الجرح والتعديل 391/4.

وإلا فسمية بصرية ،قال عنها ابن حجر : مقبولة من الثالثة. -

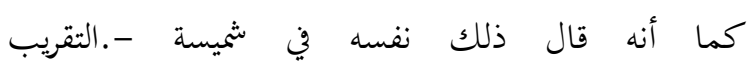

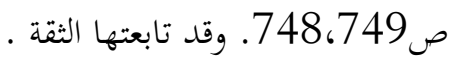
وسكت عليه أبو داوود فهو عنده صالخ. • م تعليق : في هذا الحديث أمور منها :

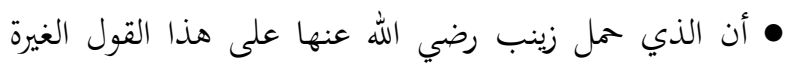
المنضمة إلى كوها من أكابر قريش فأراد النبي صلى الله على عليه وسلم تذذيبها وتأديبها فهجرها تلك المدة. • فيه جواز الهجران فوق ثلاث لفعل القبيح على قصد الزجر

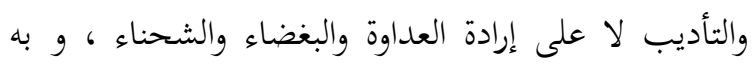

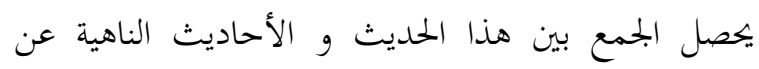

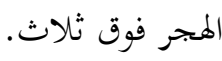


أخبرتها ، إن الله لم يبعثني معنتا ولا متعنتا

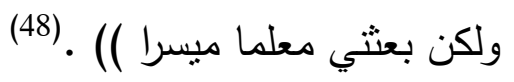

(48) حديث صحيح ، رواه مسلم في صحيحة ، كتاب

الطلاق، باب بيان أن تخيير امرأته لا يكون طلاقا إلا بنية ،

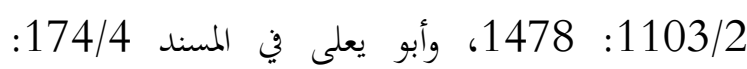

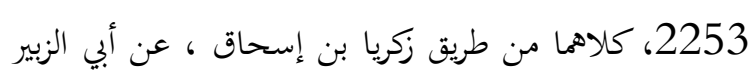
، عن جابر رضي الله عنه ، فذكره.

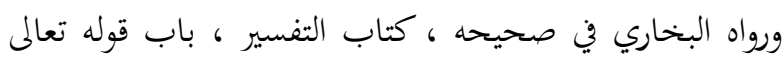

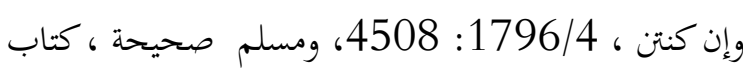

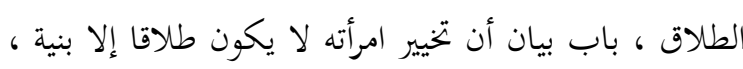

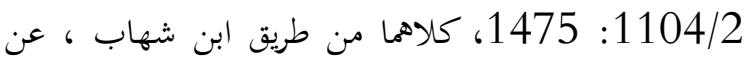

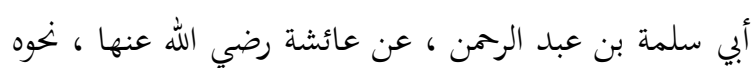

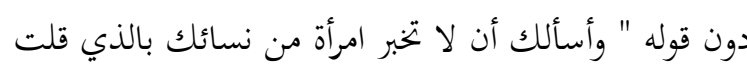

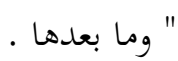

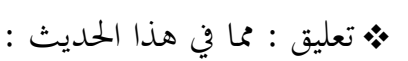

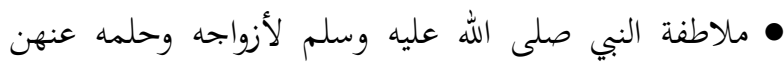
وصبره على ما كان يصدر منهن .

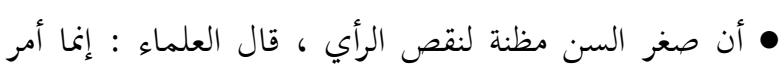

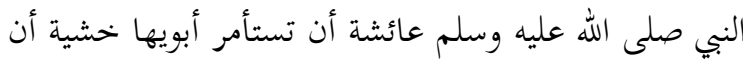

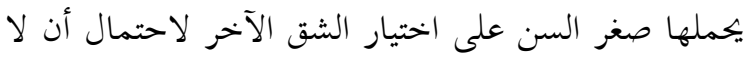

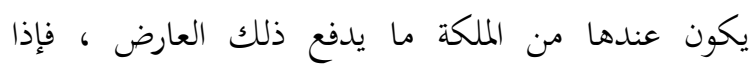

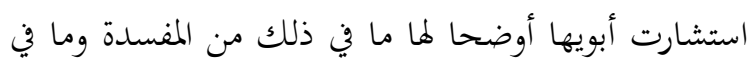
مقابله من المصلحة . • منقبة عظيمة لعائشة وبيان كمال عقلها وصحة رأيها مع مع معابه

$$
\text { صغر سنها . }
$$

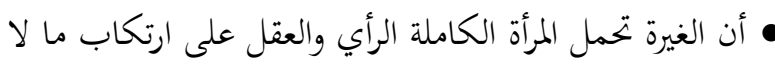

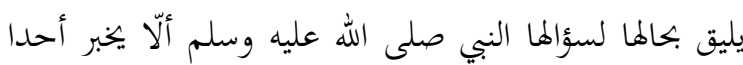

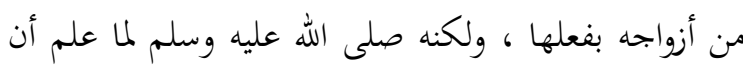

شيئًا أضحك النبي صلى الله عليه وسلم . فقال: يا رسول الله لو رأيت بنت خارجة سألنتي النفقة فقدت إليها فوجأت عنقها(47). فضحك رسول الله صلى الله عليه وسلم ، فئل وقال : هن حولي كما ترى يسألنني النفقة . فقام أبو بكر إلى عائشة يجأ عنقها ، فقام لري عمر إلى حفصة يجأ عنقها ، كلاهما يقول إنى : تسألن رسول الله صلى الله عليه وسلم ما لها ليس عنده ! فقلن : واله لا نسأل رسول اله

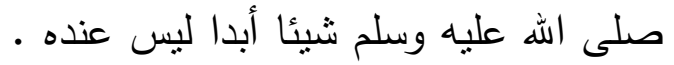
ثم اعتزلهن شهرا أو تسعا وعشرين ، ثم الثه

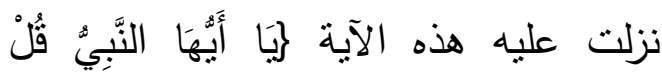
لِأَزْوَاجِكَ

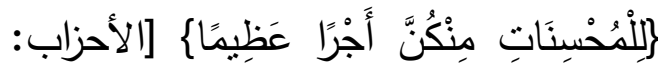

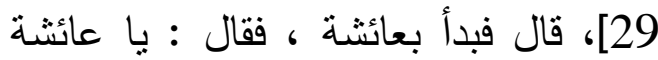
إني أريد أن أعرض عليك أمرا أحب أن لا لا لهان تعجلي فيه حتى نستشيري أبويك ـ قالت :

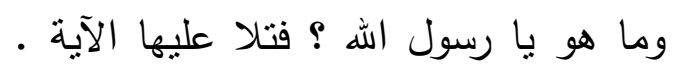

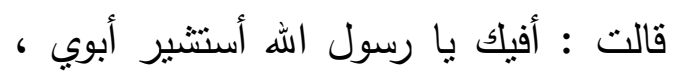

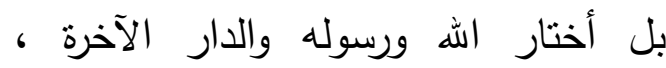
وأسألك أن لا تخبر امرأة من نسائك بالذي

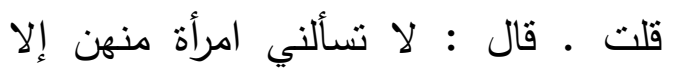

(47) أي دقها ، يقال : وجأ عنقه يجأهاوجئا ، إذا دقها . ينظر تفسير غريب ما في الصحيحين ص 223. 
16. عـن عائشــة رضـي الله عنهـا ، قالت :

(استأذنت هالـة بنت خويلـ أخت خديجة

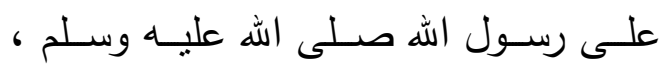

فعرف استئذان خديجة فارتاع لذلك ، فقال:

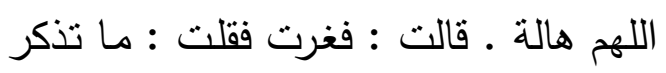

مـن عجـوز مـن عجـائز قـريش حمـراء

الثدقين هلكت في الدهر قد أبدلك الله خيرا

منها)().

ورواه مسلم في كتاب فضائل الصحابة رضي الله عنهم ، باب

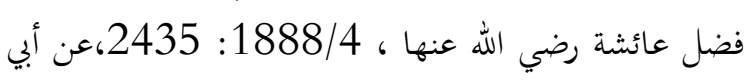

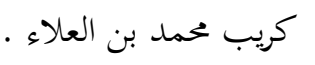

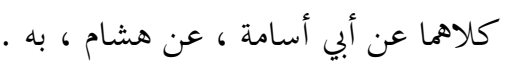

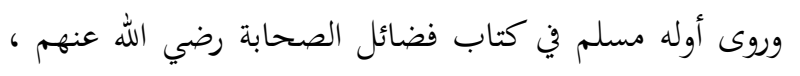

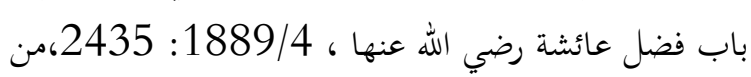

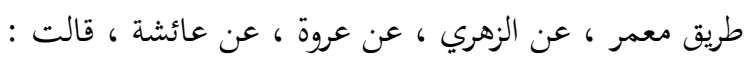

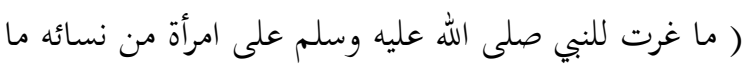

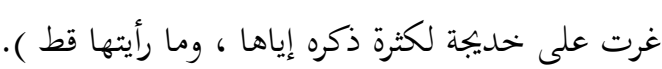

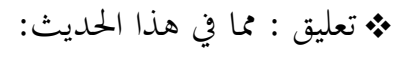

• حسن عهد النبي صلى الله عليه وسلم وحفظه الود ورعايته : مدائه

حرمة الصاحب والمعاشر حيا وميتا ، وإكرام معارفه.

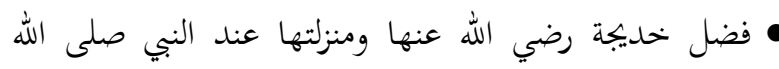

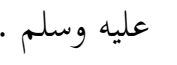

• عدم مؤاخذته صلى الله عليه وسلم لعائشة لقيام معذرقا

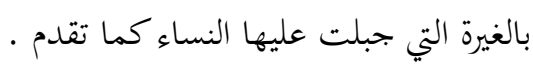

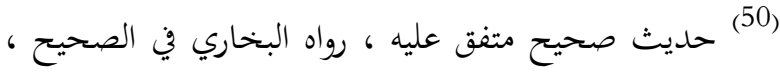

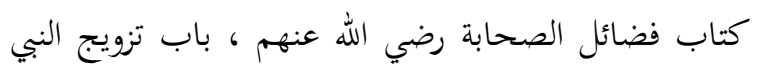

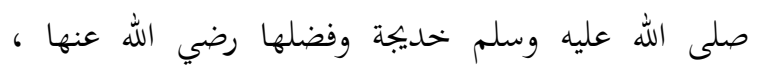
1389/3: 3610، عن إسماعيل بن خليل .
15. عـن عائشــة رضـي الله عنهـا ، قالـت :

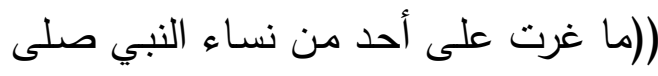

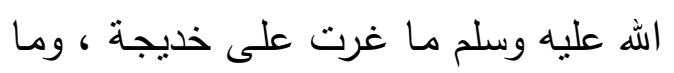

رأيتها ولكن كان النبي صلى الله عليه وسلم

يكثر ذكرهـا ، وربمـا ذبـح الثـاة ثم يقطعها

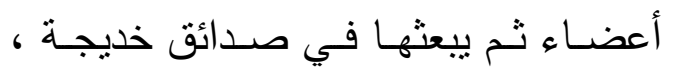

فربما قلت له : كأنه لم يكن في الدنيا امرأة

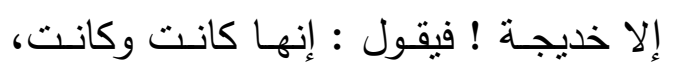

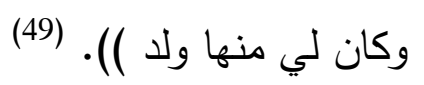

الحامل لها على ذلك ما طبع عليه النساء من الغيرة ومحبة

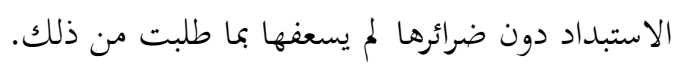

قاله ابن حجر في فتح الباري 522/8.

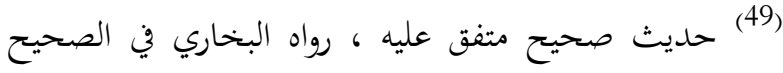

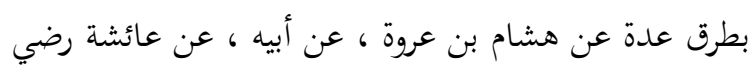
الله عنها .وتابعه مسلم في طريقين منها متابعة قاصرة .

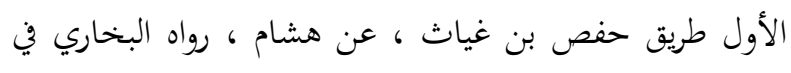

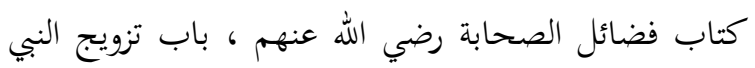

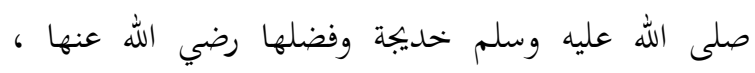

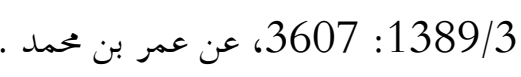

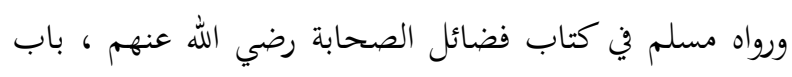

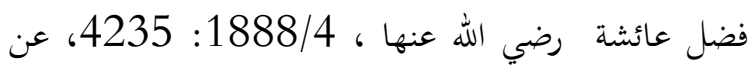

سهل بن عثمان

كلاهما عن حفص بن غياث ، عن عنان ، هشام ، به.

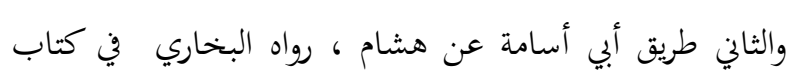

الآداب ، باب حسن العهد من الإيمان ، 2237/5:

5658، عن عبيد بن إسماعيل . الآداب ، باب العهد من 


$$
\begin{aligned}
& \text { لعمـري فــن يغــى بألبـان الضــأن ليحسـن } \\
& \text { 17. عـن عائثــة رضـي الله عنهـا قالـت : }
\end{aligned}
$$

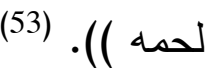

$$
\begin{aligned}
& \text { (أهدى ملـك مـن بطارقـة الـروم يقـال لـهـ }
\end{aligned}
$$

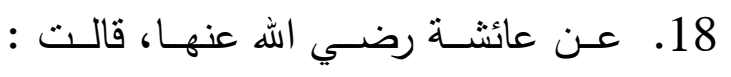

$$
\begin{aligned}
& \text { (كنـ أغـار على اللاتـي وهـبن أنفسـهن }
\end{aligned}
$$

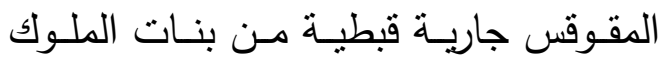

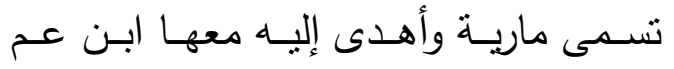

$$
\begin{aligned}
& \text { لرسول الله صلى الله عليه وسلم ، وأقول : }
\end{aligned}
$$

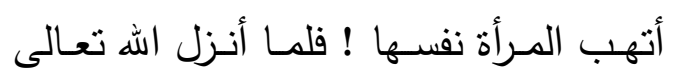

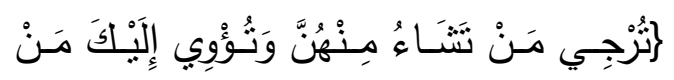

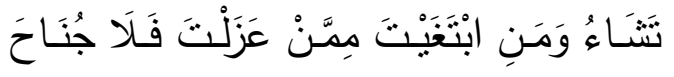

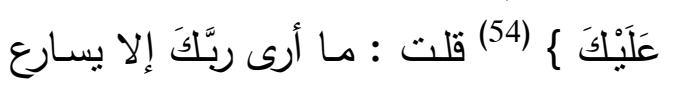

$$
\begin{aligned}
& \text { في هوَاكَ (). } \\
& \text { 1324) ضعيف ، رواه ابن أبي عاصم في الآحاد والمثاني 447/5: } \\
& \text { 1324، من طريق الليث بن سعد . } \\
& \text { والحاكم في المستدرك 1324، من طريق الليث بن سعد 6821/4، من طريق سليمان بن }
\end{aligned}
$$

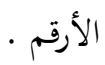

$$
\begin{aligned}
& \text { كلاهما عن الزهري ، عن عروة ، عن عائشة رضي الله عنها. }
\end{aligned}
$$

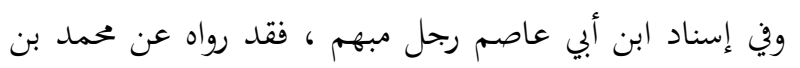

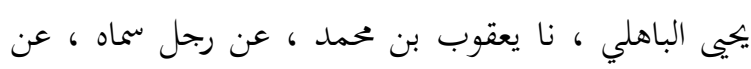

$$
\begin{aligned}
& \text { الليث. } \\
& \text { وفي إسناد الحاكم سليمان بن أرقم وهو متروك الحديث. }
\end{aligned}
$$

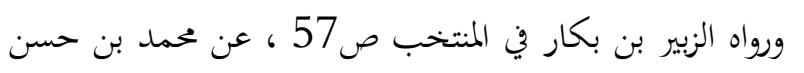

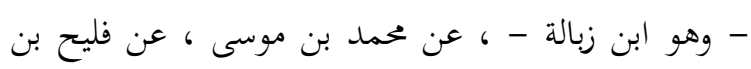

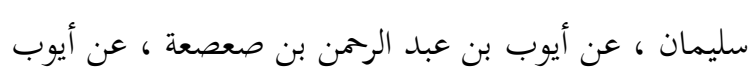

$$
\begin{aligned}
& \text { بن بشير ، قال : قالت عائشة ـ فذكر معناه. } \\
& \text { وهو إسناد ساقط ، فيه محمد بن حسن متروك. }
\end{aligned}
$$

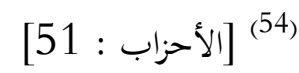

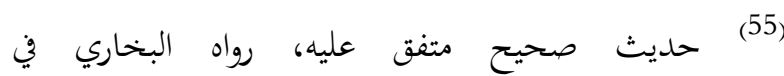

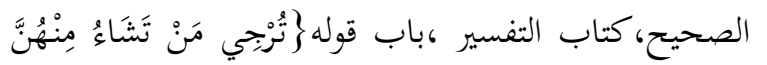

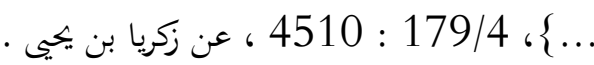

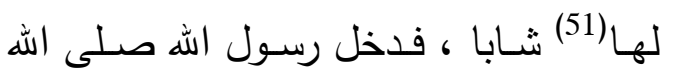

$$
\begin{aligned}
& \text { عليه وسلم منها ذات مدخل خلوة فأصسابها } \\
& \text { فحملت إبراهيم ، قالت عائشــة رضـي الله } \\
& \text { عنها : فلما استبان حملها جزعت من ذللك } \\
& \text { فسكت رسول الله صلى الله عليه وسلم حتى }
\end{aligned}
$$

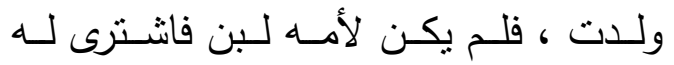

$$
\begin{aligned}
& \text { ضائنة لبونا فغذي منها الصبي فصلح عليه } \\
& \text { جسمه وحسن لحمـه وصفا لونهـ ، فجاء بـه } \\
& \text { ذات يوم يحمله على عنقه فقال : يا عائشة } \\
& \text { كيف ترين الثبه ؟ فقالت وأنا غيرى(52) : } \\
& \text { مـا أرى شبها ـ فقال : ولا اللحم ؟ فقلت : } \\
& \text { ومسلم في الصحيح ، كتاب فضائل الصحابة رضي الله عنهم ، } \\
& \text { باب فضل خديجة رضي الله عنها ، 1889/4: }
\end{aligned}
$$

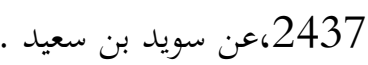

$$
\begin{aligned}
& \text { كلاهما عن علي بن مسهر ، عن هشام ، عن أبيه ، عن عائشة } \\
& \text { رضي الله عنها. }
\end{aligned}
$$

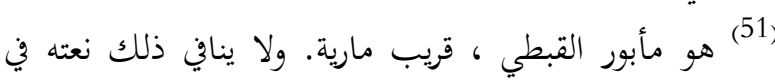

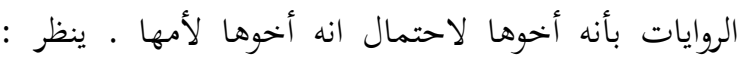

$$
\begin{aligned}
& \text { 699/5. الإصابة }
\end{aligned}
$$

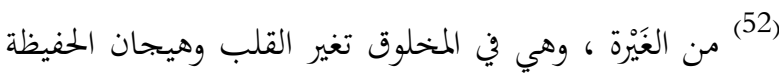

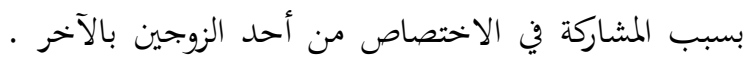

$$
\begin{aligned}
& \text { ينظر مشارق الأنوار 141/2. }
\end{aligned}
$$


عهد رسول الله صلى الله عليه وسلم الذي

عهد إليه . (56) عند

(56) صحيح ، رواه أحمد في المسند 6/ 114:

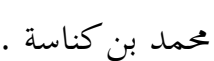

وابن شاهين في الكتاب اللطيف صناسة ـ 154، وأبو نعيم في

الخلفاء الراشدين ص65، كلاهما من طريق بشر بن الوليد.

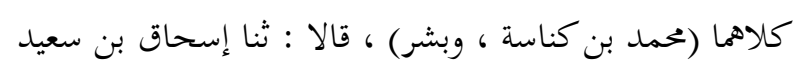

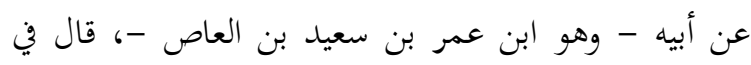

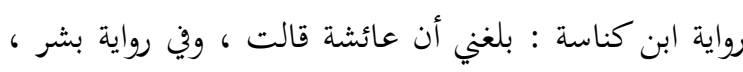

عن عائشة . فهو منقطع بين سعيد وعائشة رضي الله عنها.

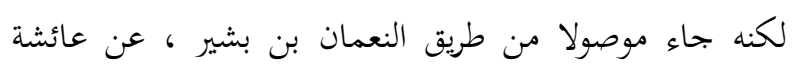

رضي الله عنهم جميعاً.

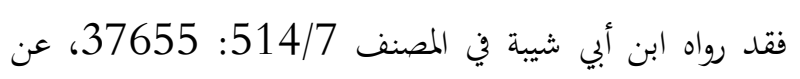

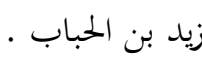

والترمذي في الجامع 628/5: 3705، من طريق ابل الليث بن

$$
\text { كلاهما عن معاوية بن صالخ. }
$$

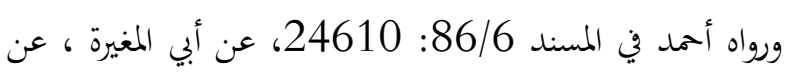

$$
\text { الوليد بن سليمان. }
$$

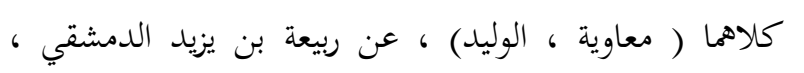

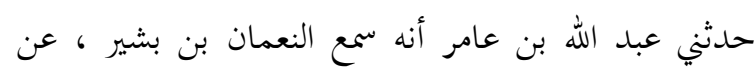

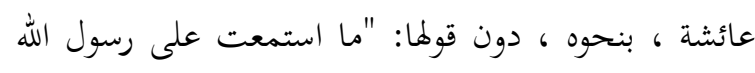

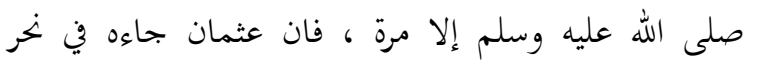

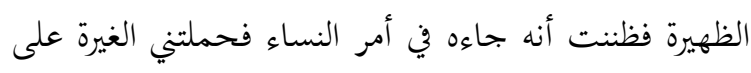

$$
\text { أن أصغيت إليه" . }
$$

وقال الترمذي هذا حديث حسن غريب ـ ـ وصححه الألباني في

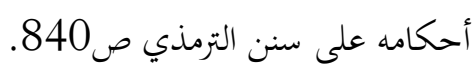

ث ثعليق : مما في هذا الحديث :
19. عن عائثـة قالت : (( ما استمعت على

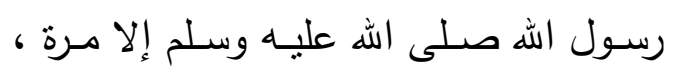

فإن عثمان جاءه في نحر الظهيرة فظننت النه

أنسه جـاءه في أمسر النسـاء فحملتتي الغيرة

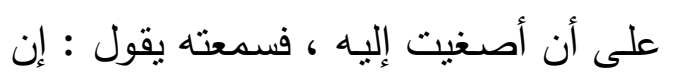

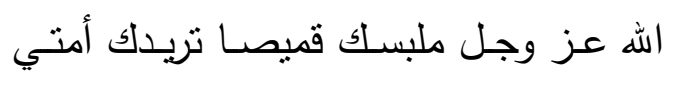

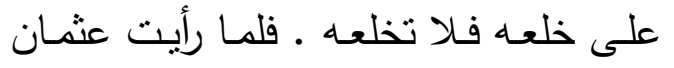

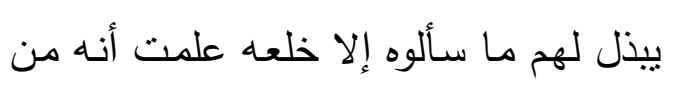

ومسلم في الصحيح ، كتاب النكاح ، باب جواز هبتها نوبتها

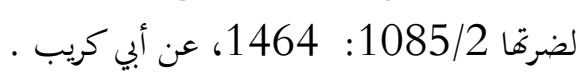

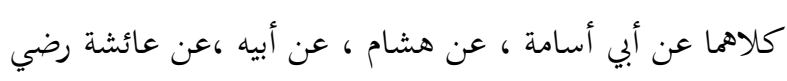

الله عنها.

وهو عند غيرهما.

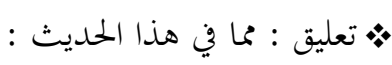

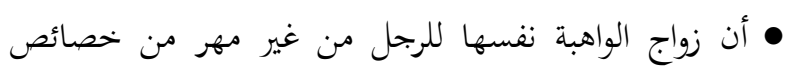

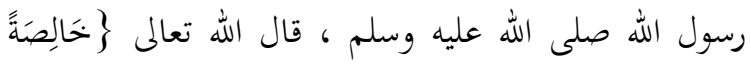

لَكَ مِنْ دُونِ الْمُوِْْنِينَ

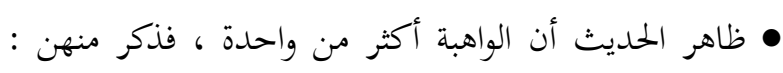

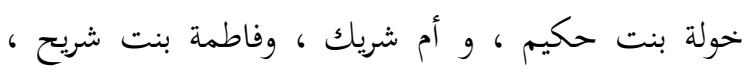

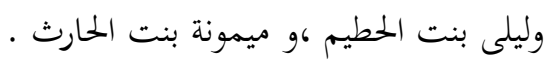

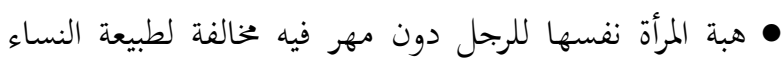

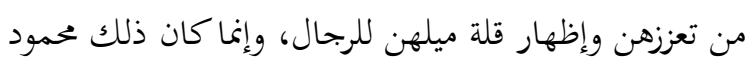

منهن لمكان النبي صلى الله عليه وسلم .

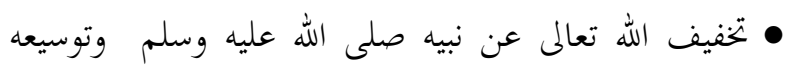

عليه في الأمور ولذا خيره . 
الله عليه وسلم ، قالت : أرسل إلي رسول

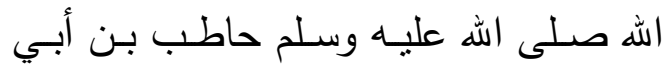

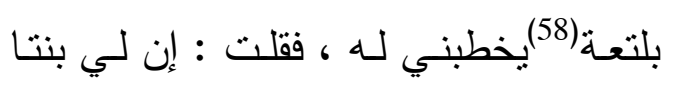
وأنا غيور .فقال : أما ابنتها فندعو الله أن

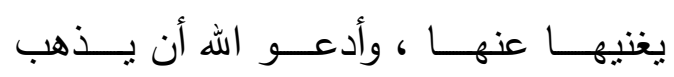
بالغيرة). (59)

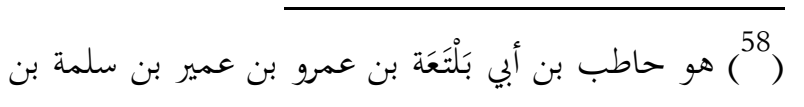

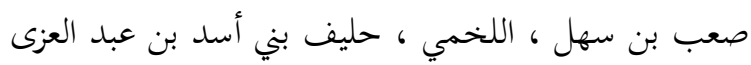

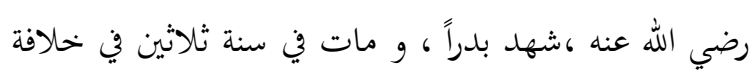
عثمان رضي الله عنه .ينظر : الإصابة 4/2. ( ) ب حديث صحيح ، رواه مسلم في الصحيح ، كتاب الجنائز

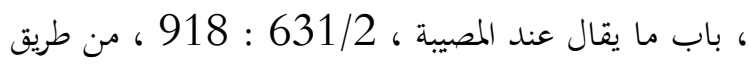

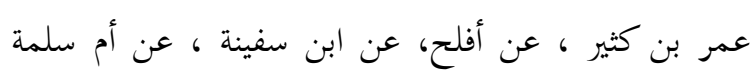

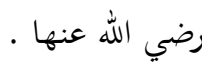
وروى أيضاً عن أم سلمة بأطول من هذا من طريق أبي بكر بن

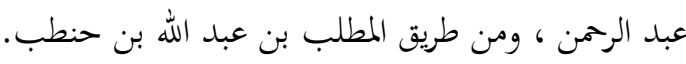

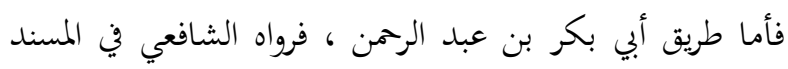

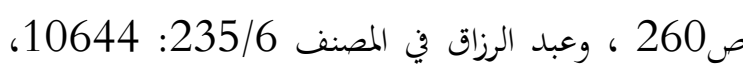

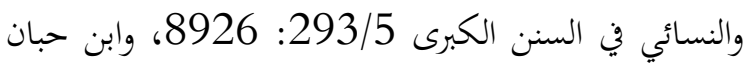

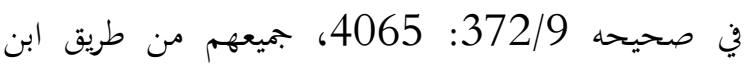

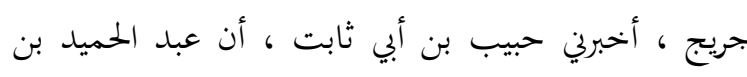

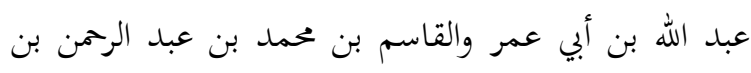

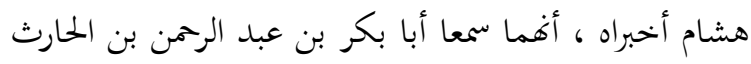

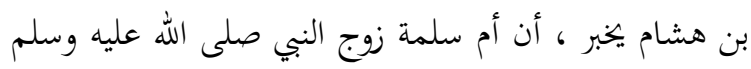
أخبرته , فذكره. وأما طريق المطلب ، فرواه أحمد في المسند 27/4: فلحكره 16388،

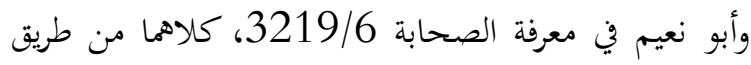

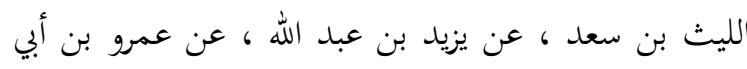

20. عن أم سلمة رضي الله عنها ، أنها قالت : (سمعت رسول الله صلى الله عليه وسلم يقول : ما من مسلم تصيبه مصيبة فيقول

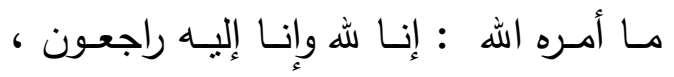
اللهم أجرني في مصييتي وأخلف لي خيرا منها ـ إلا أخلف الله له خيرا منها ـ قالت : الهي

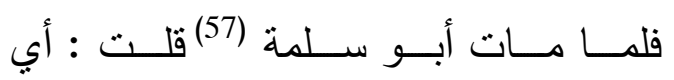
المسلمين خير مـن أبي سـلمة ، أول بيت

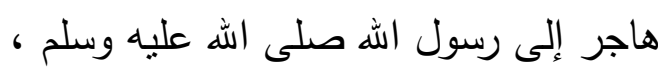
ثم إني قلتها فأخلف الله لي رسول الله صلى

• قوله صلى الله عليه وسلم لعثمان رضي الله عنه "إن الله عز وجل ملبسك قميصا تريدك أمتي على خلعه فلا تخلعه" فيه

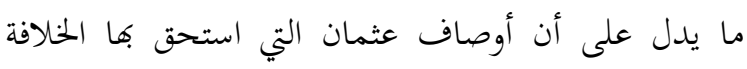

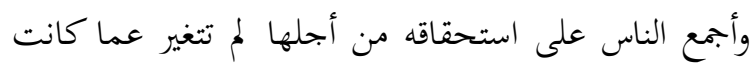

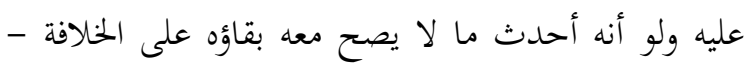

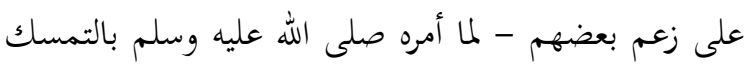

• تفرد عثمان رضي الله عنه بهذه الفضيلة التي لم يشركه فيها

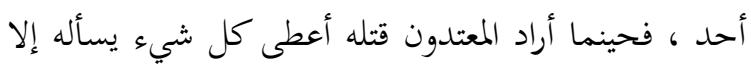

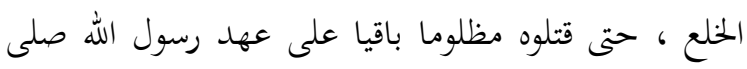

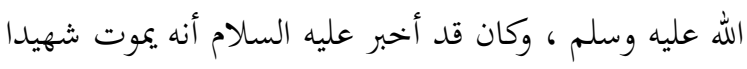

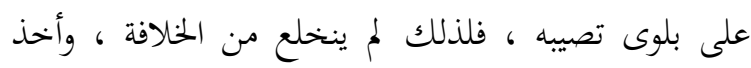
بالشدة على نفسه طلبا لعظيم الأجر.

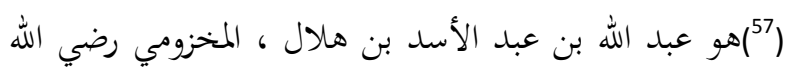

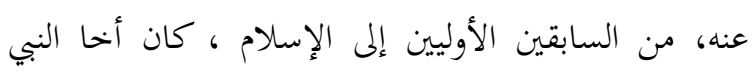

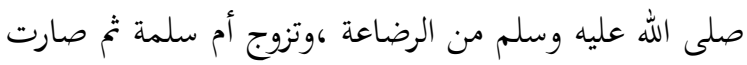

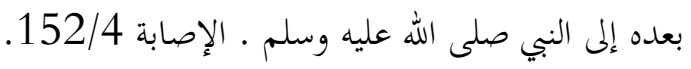


الأنصـار ؟ قال : إن فيهم لغيرة شديدة )).

( ) حديث ضعيف ، رواه حماد بن سلمة واختُلِف عليه في

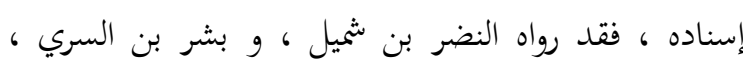

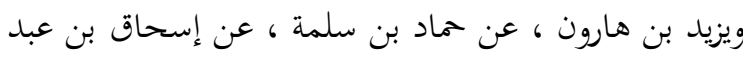
الله ، عن أنس رضي الله عنه.

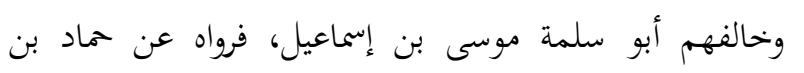

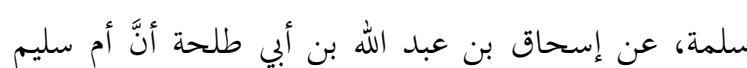

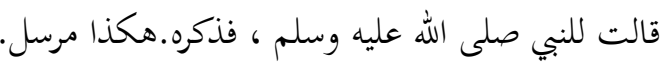

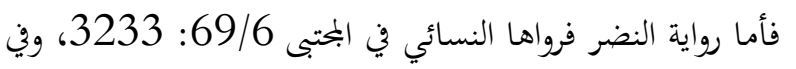

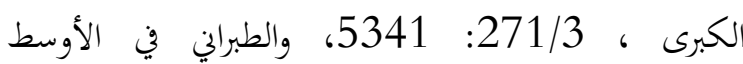
139/8: 8207، كلاهما من طريق إسحاق بن راهويه.

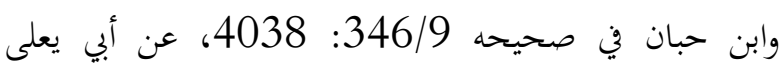
الموصلي ،عن خلاد بن أسلم . والضياء في المختارة 368/4: 1534، ، مناد بن الميل طريق القاضي أبي بكر الميانجي ، عن أبي يعلى ، عن خلاد الماد.

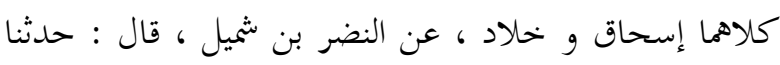

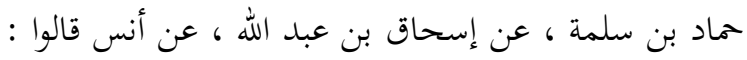
يا رسول الله ، فذكره. ولفظ ابن حبان ( قال : إن في أعينهم شيئاً ) ، ولذا ذكر في

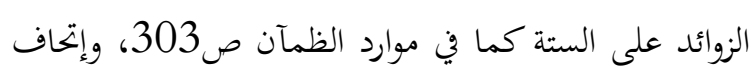

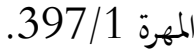
وأما رواية بشر فرواها الضياء في المختارة 368/4: 1535،

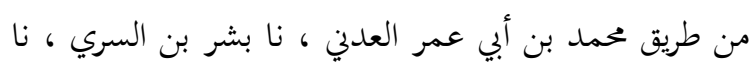

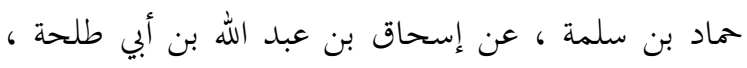

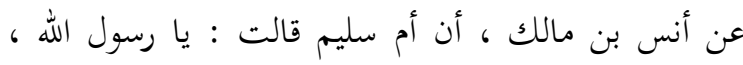

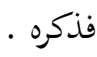

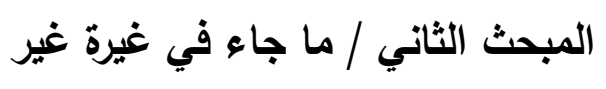

ورواية المطلب عن أم سلمة مرسلة ، قال الترمذي : " سألت فئل

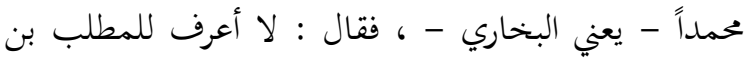

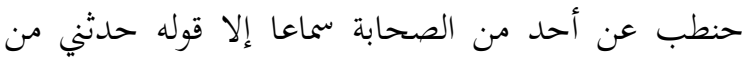

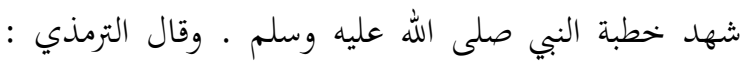

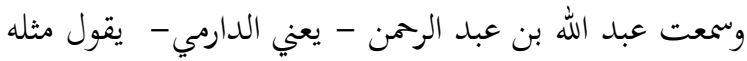

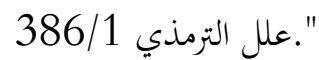
وقال ابن أبي حاتم : " سمعت أبي يقول : المطلب بن عبدالله بن المبل

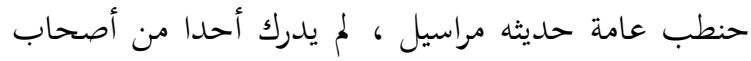

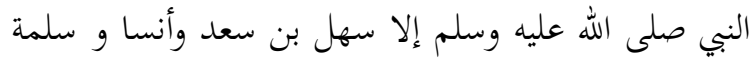

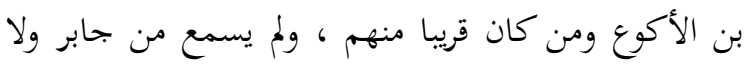

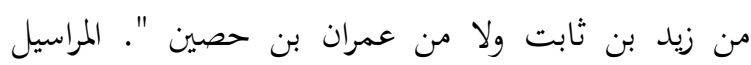

.210/1

* ثعليق : محا في هذا الحديث:

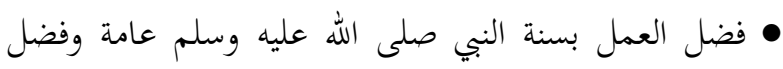

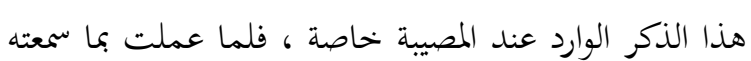
من رسول الله صلى الله عليه وسلم آجرها الله في مصيبتها بفقد زوجها وأخلفها بخير خلقه أجمعين. • أن الدعاء من أهم وسائل معالجة الغيرة . 


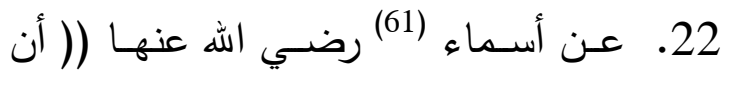

امرأة (62) قالت : يا رسول الله إن لي ضرة الهن

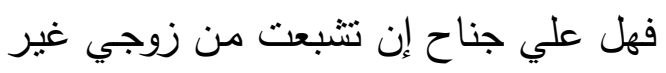

الذي بعطيني ؟ فقال رسول اله صلى الهـ

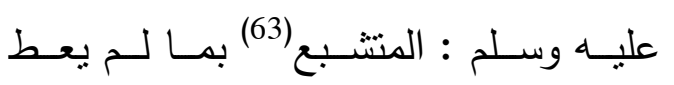

كلابس ثوبي زور ()) . (64)

سليم قالت للنبي صلى الله عليه وسلم ...مرسل. وسمعت

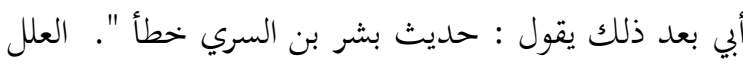

.400/1

وهو حديث ضعيف لانقطاعه بين إسحاق وأم سليم رضي الله

(61) هي أسماء بنت أبي بكر الصديق رضي الله عنهما، و والدة

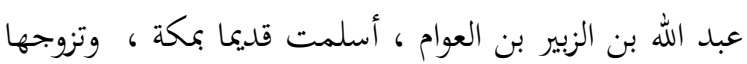

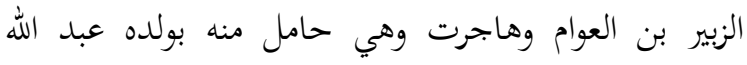

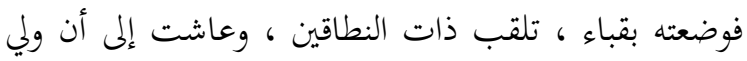

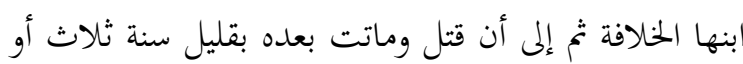

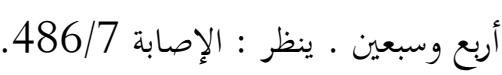
(62) لم أقف على اسمها ولا اسم زوجها.

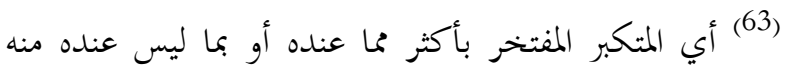
شيء .تفسير غريب ما في الصحيحين ص 556.

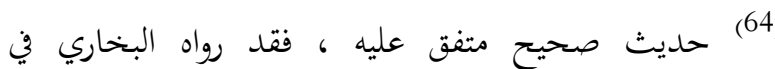

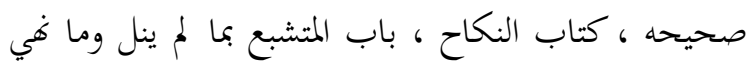

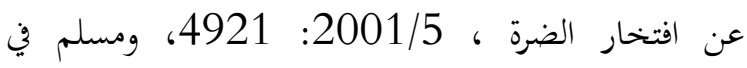
صحيحه ، كتاب اللباس والزينة ، باب النهي عن التزوير في

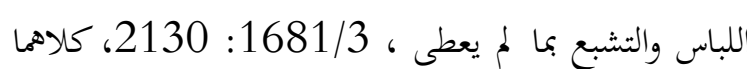

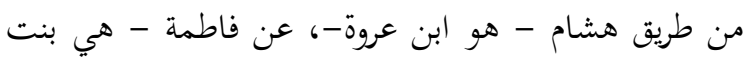

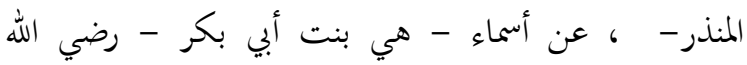

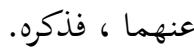

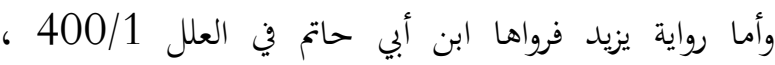

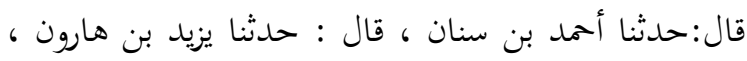

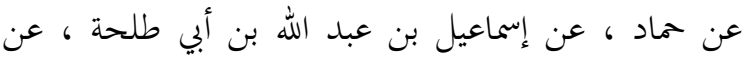

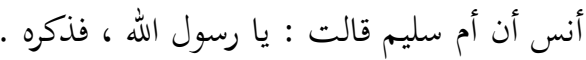

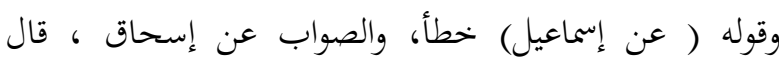

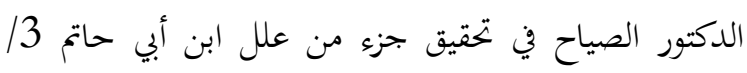

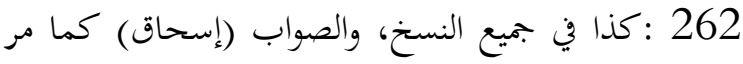

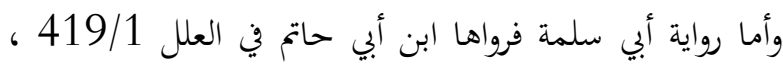

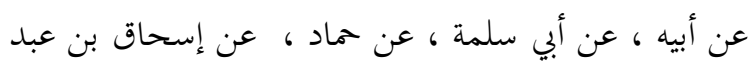
الله بن أبي طلحة أنَّ أم سليم قالت للنبي صناد، عنى الله عليه

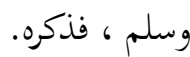

والأقرب أن الاختلاف من حماد بن سلمة نفسه فالرواية المتصلة رواها عنه ثلاث كلهم ثقات ، و والمنفرد عنه بالرواية المرسلة ثقة ثبت ، وقد نسب له الخطأ ، قال مسلم في التمبيز

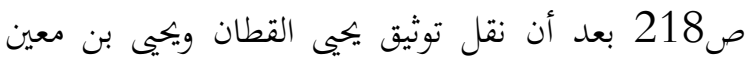

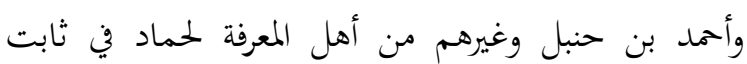

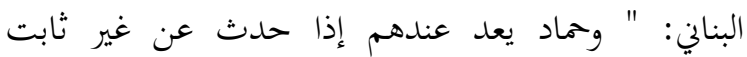

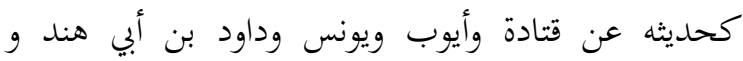

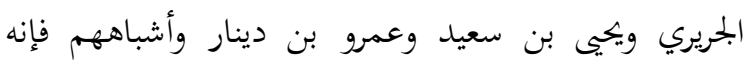

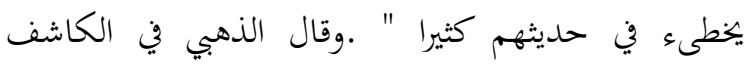
ص349: " يغلط وليس في قوة مالك ".

وقد خطأَألرواية المتصلة أبو حاتم وأبو زرعة ورجحا المرسلة ، قال

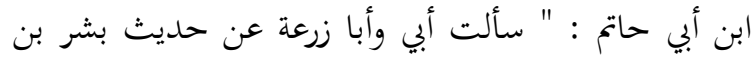

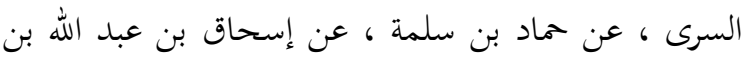

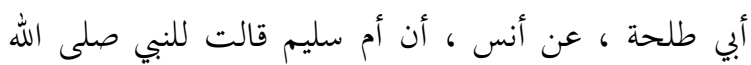

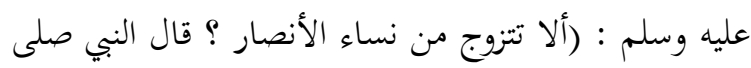

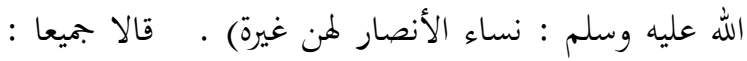

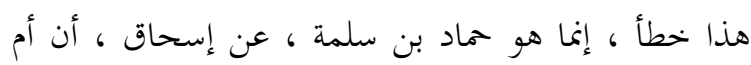


فيـهـ غـرة (68)، قـال : وجعلـه علـى عاقلـة

المرأة (). (69)

(68) الغرة عند العرب أنفس شيء يُملك ، والغرة التي يودَّى بها

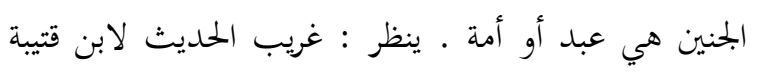

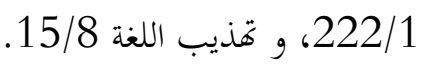

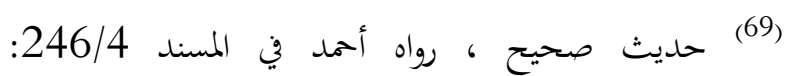

18173،والدارمي في السنن 257/2: 2380: 2380، وأبو داود المداد

في السنن 190/4: 4568، والنسائي في البمتبى 1868:

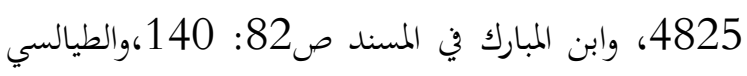

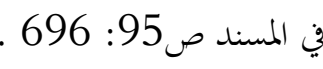

جميعهم من طريق شعبة .

ورواه مسلم في الصحيح ، كتاب القصاص والديات ، باب دية 1682، بندية

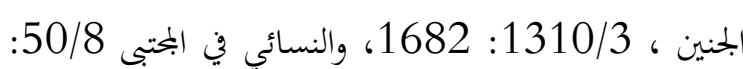

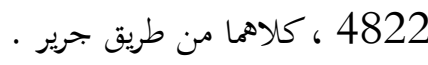

ورواه النسائي في البختى 50/8: كاهما طن طريق 4823 ورئ و أحمد في المسند 245/4: 18163، كلاهما من طريق سفيان .

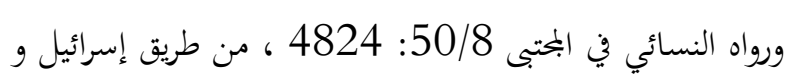

جميعهم عن منصور بن المعتمر ، عن إبراهيم التيمي ، عن عبيد

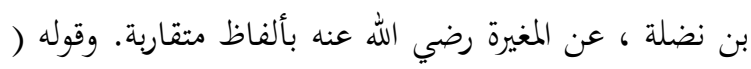

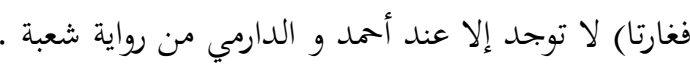

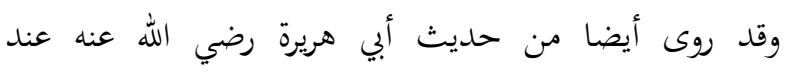

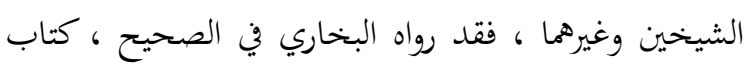

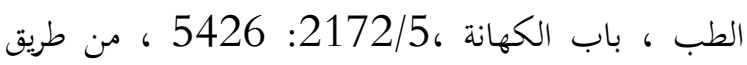

عبد الرممن بن خالد ، عن ابن شهاب ، عن أبي سلمة.

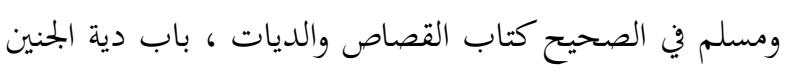

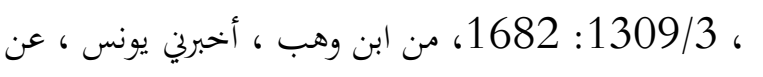

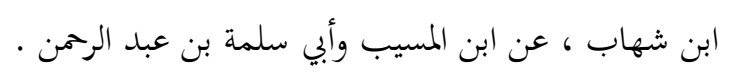

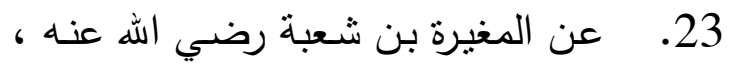

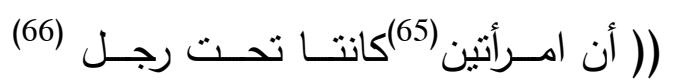

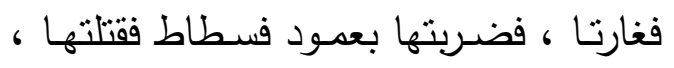

فاختصـموا إلى رسـول الله صـلى الله عليـه

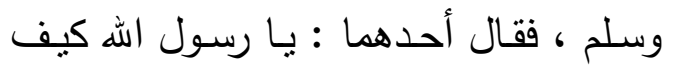

نُـدِي مـن لا أكـل ولا شــرب ولا صـــاح ولا

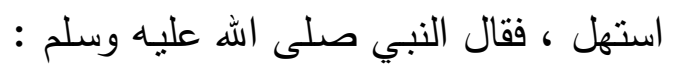

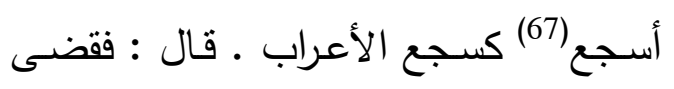

ورواه مسلم في صحيحه ، كتاب اللباس والزينة ، باب النهي

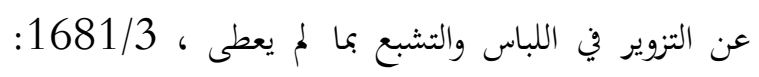

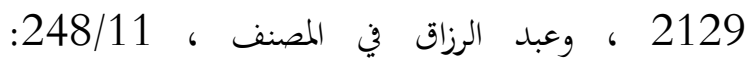

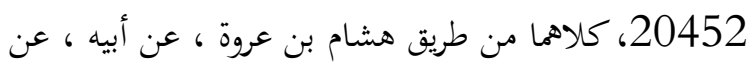
عائشة رضي الله عنها ، نغوه.

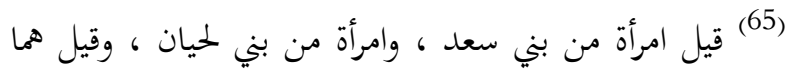

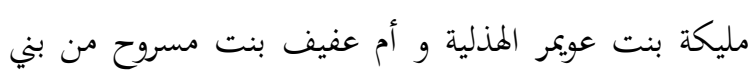

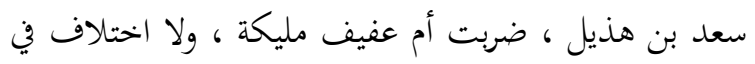

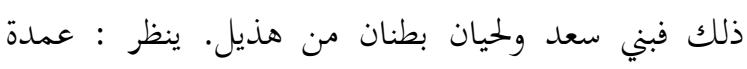
243/23. - القاري (66) هو حمل بن مالك بن النابغة المذلي.

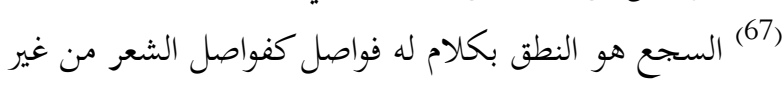

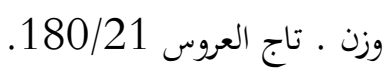




$$
\begin{aligned}
& \text { الغيرة على النسـاء والجهاد على الرجل ، } \\
& \text { 24. عـن ابـن مسـعود - رضـي الله عنـهـ- } \\
& \text { فمن صبر منهن كان لها أجر شهيد)). (70) } \\
& \text { الخاتمة } \\
& \text { في نهاية هذا البحث أجمل أهم ما توصلت إليه من } \\
& \text { نتائج : فه } \\
& \text { قال : ((كنت جالسا مـع النبي - صلى الله } \\
& \text { عليه وسلم - ومعحه أصحابه إذ أقبلت امرأة } \\
& \text { عريانـة ، فقام إليهـا رجل مـن القوم فـألقى } \\
& \text { عليها ثوبا وضمها إليه ، فتغير وجه رسول } \\
& \text { 1. أن النساء مفطورات على الغيرة وهي جبلة } \\
& \text { فيهن. } \\
& \text { 2. الغيرة ما دامت في حدود ما جبلت عليه } \\
& \text { النساء فهي من المسموح به المعفو عنه. } \\
& \text { (70) } \\
& \text { 1490:308/4، عن يوسف بن محمد ، ومحمد بن عمارة } \\
& \text { بن صبيح } \\
& \text { ورواه ابن الأعرابي في معحمه ، ص425: 829، عن أممد بن } \\
& \text { حازم . }
\end{aligned}
$$

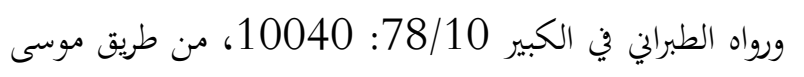

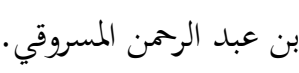

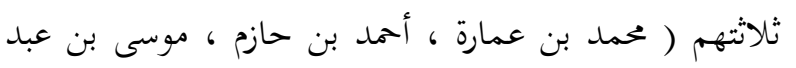

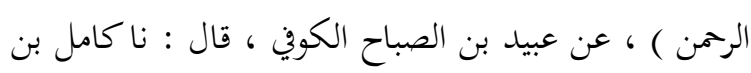

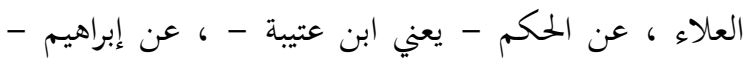

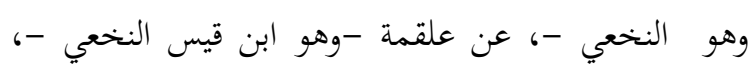

$$
\begin{aligned}
& \text { عن عبد الله رضي الله عنه ، به. } \\
& \text { ومدار إسناده على عبيد بن الصباح وهو ضعيف ، ضعفه أبو }
\end{aligned}
$$

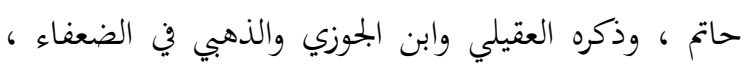

$$
\begin{aligned}
& \text { وقال العقيلي : " لا يتابع على حديثه ولا يعرف إلا به "لحنه ". }
\end{aligned}
$$

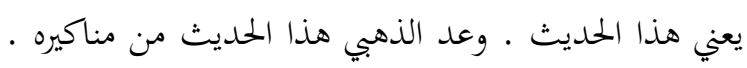

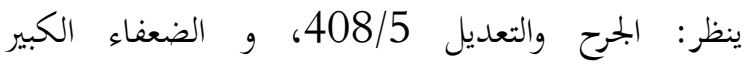

$$
\begin{aligned}
& \text { 117/3، وميزان الاعتدال 26/5. } \\
& \text { الله - صلى الله عليه وسلم - ، فقال بعض وهله } \\
& \text { أصـحابه : أحسبها امرأتـه .فقـال النبـي الهيه } \\
& \text { أحسبها غيرى ، وأن اله تبارك وتعالى كتب أبه }
\end{aligned}
$$

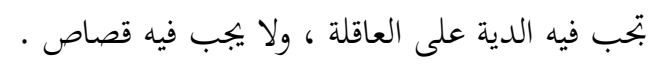

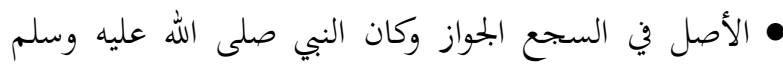

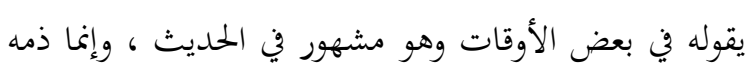

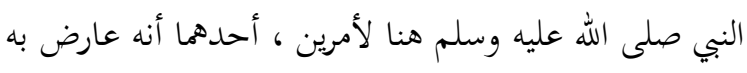

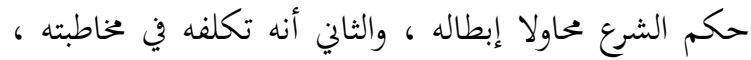

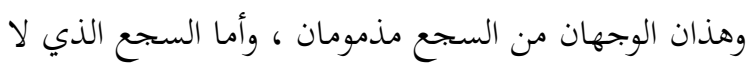

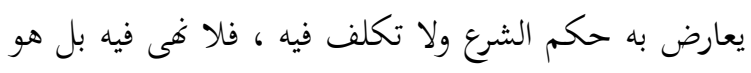

$$
\begin{aligned}
& \text { • أن النبي صلى الله عليه وسلم لم يعاقبه لأنه مأمور بالصفح }
\end{aligned}
$$

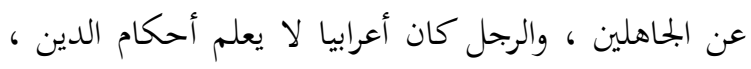

$$
\begin{aligned}
& \text { فعاب صلى الله عليه وسلم فعله ولم ينتقم لنفسه. }
\end{aligned}
$$

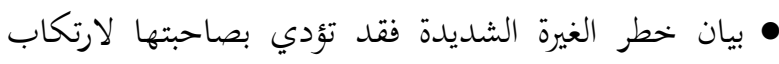

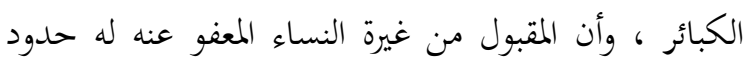

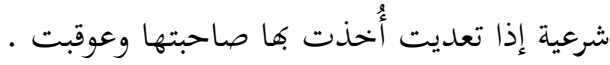


أحمد محمد نور سيف، دمشق: دار المأمون

$$
\text { للتراث. }
$$

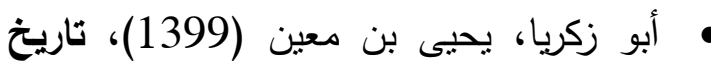

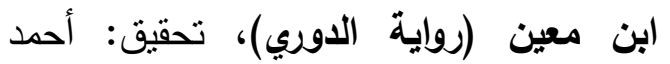

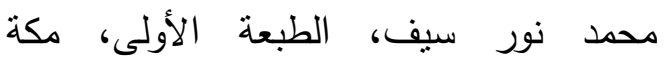

المكرمة: مركز البحث العلمي واحياء التراث

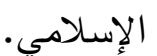

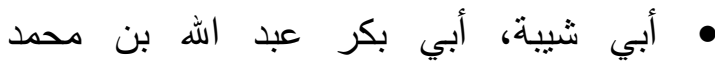

(1997)، مسند ابن أبي شيبة، تحقيق: عادل آبرل

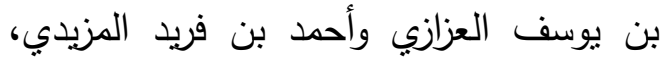
الطبعة الأولى، الرياض: دار الوطن.

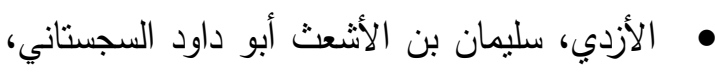

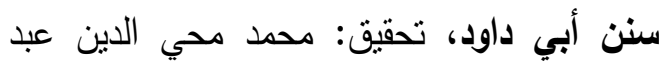

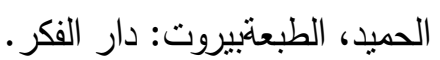

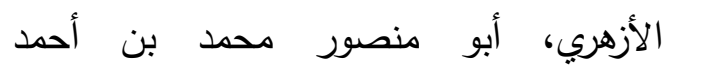

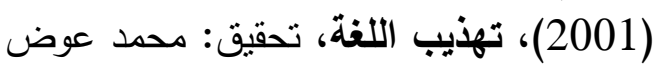

مرعب، الطبعة الأولى، بيروت: دارئ دار إحياء

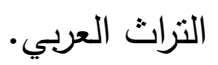

الأصبهاني ، أحمد بن عبد الله بن أحمد ، أبو الكي

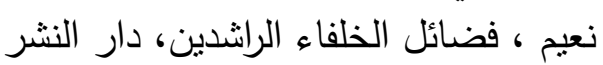

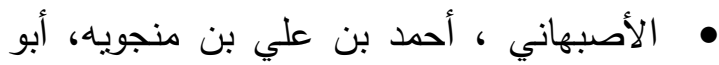

بكر (1407)، رجال صحيح مسلم، تحقيق:

عبد الله الليثي، الطبعة الأولى، بيروت: دار مدئ، تحفي

المعرفة.

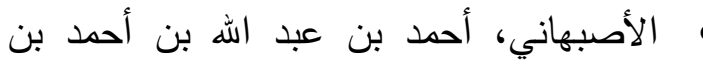

إسحاق بن موسى بن مهران الهراني ، أبونعيم الأني

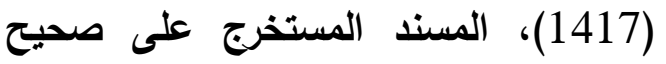

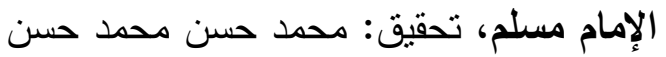

إسماعيل الثافعي، الطبعة الأولى، بيروت: دار الكتب العلمية.

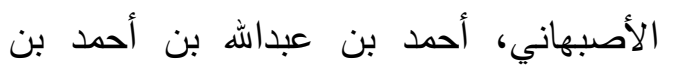

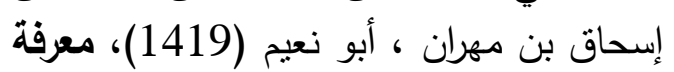

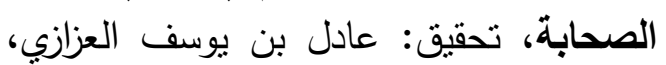

الطبعة الأولى، الرياض: داض: دار الوطن.
3. غيرة أمهات المؤمنين لا تحمل على الذم ؛

لأنها في حدود ما جرت به عادات الضرائر

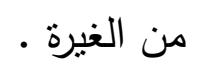

4. عظيم حسن خلق النبي صلى اله عليه

وسلم وحلمه على نسائه عند الغيرة.

5. أن من هديه صلى الله عليه وسلم إنصاف وسله

من وقع عليها الحيف في الغيرة.

6. أهمية الاقتداء بالنبي صلى اله عليه وسلم

في تعامله مع غيرة النساء.

7. اشتمل هذا البحث على أربعة وعثرين

حديثاً ، الصحيح منها عشرون ، والباقي

ضعيف.

\section{قائمة المصادر والمراجع}

$$
\text { • القرآن الكريم }
$$

• ابن القيم ، الدمشقي، شمس الدين محمد بن

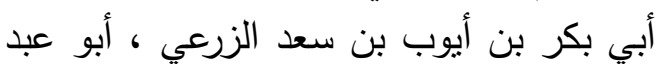

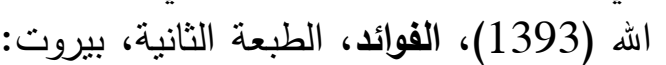
دار الكتب العلمية.

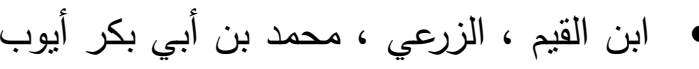

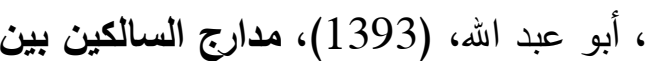
منازل إياك نعبد واياك نستعين، تحقيق: محمد حامد الفقي، الطبعة الثانية، بيروت : دار

$$
\text { الكتاب العربي. }
$$

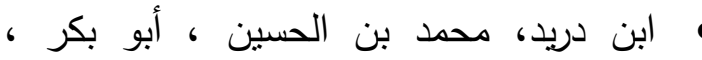
(1987) ، جمهرة اللغة، تحقيق: رمزي منير بعلبكي، الطبعة الأولى.

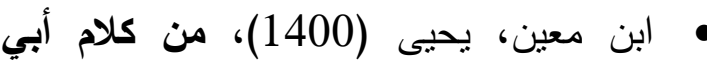
زكريا يحيى بن معين في الرجال، تحقيق: د. د. دين 


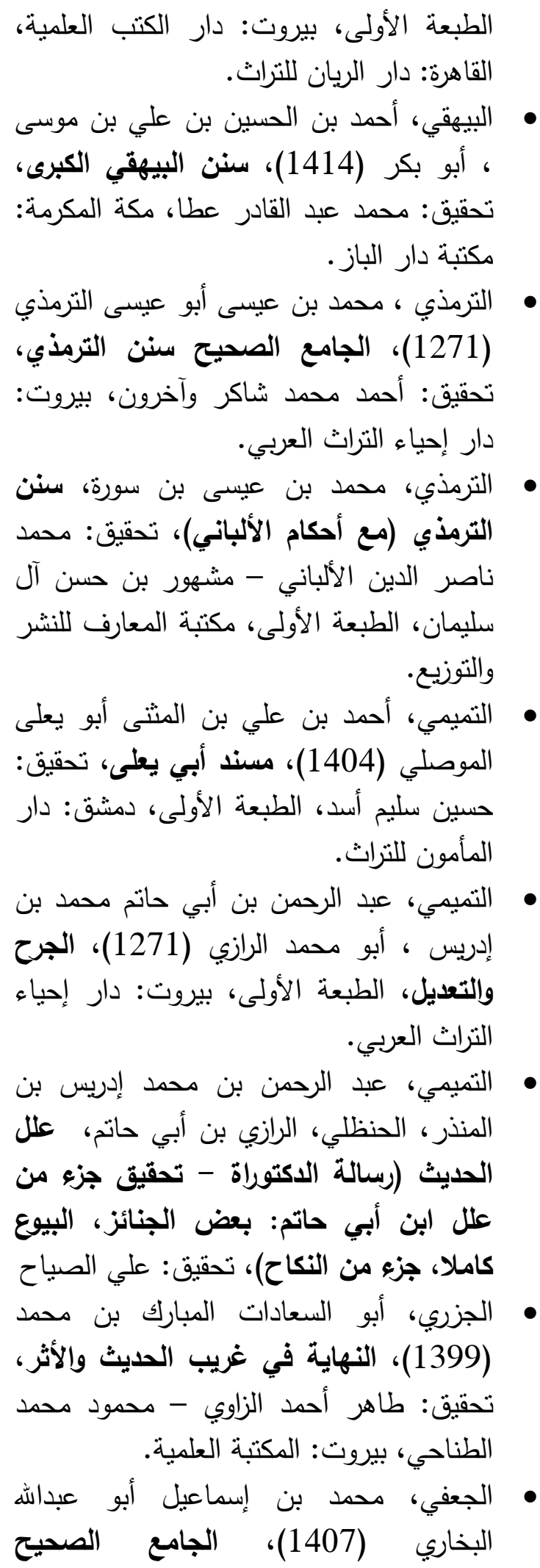


ه الحنظلي، إسحاق بن إبراهيم بن مخلد بن إنبه

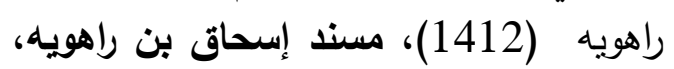

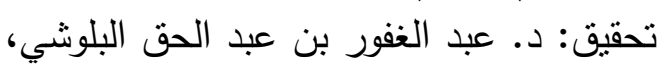

الطبعة الأولى، المدينة المنورة: مكتبة الإيمان.

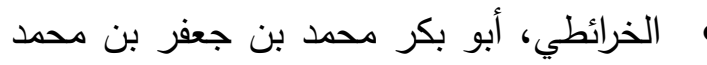

بن سهل بن شاكر ، اعتلال القلوب، تحقئ بنديق

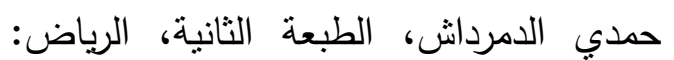

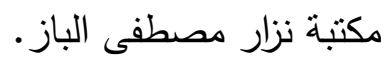

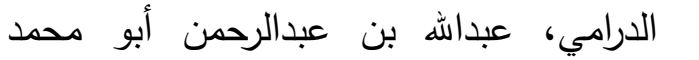

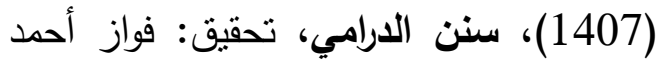

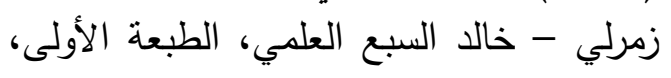
بيروت: دار الكتاب العربي.

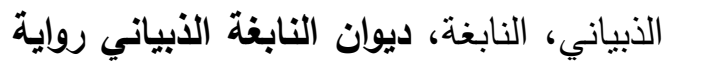

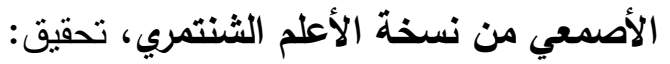
محمد أبو الفضل من إبراهيم، الطبعة الثبن الثنانية، القاهرة: دار المعارف.

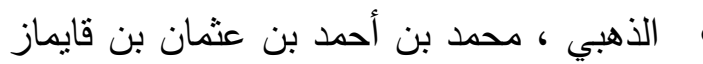

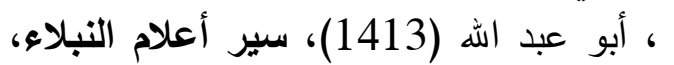

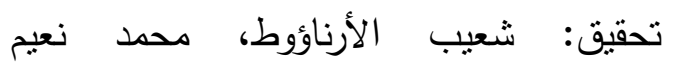
العرقسوسي، الطبعة التاسعة، بيروت: مؤسسة لرعة

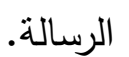
•الذهبي ، محمد بن أحمد بن عثمان بن قايماز

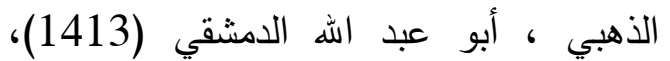

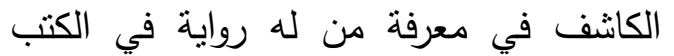

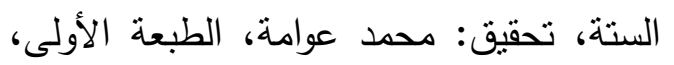
جدة: دار القبلة للاققافة الإسلامية، مؤسسة الطية الأبة

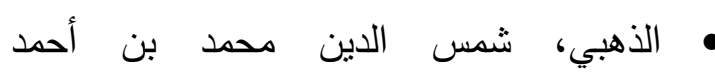
(1995)، ميزان الاعتدال في نقا الرجال،

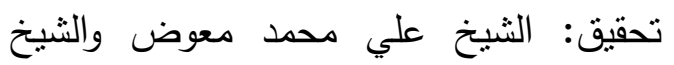

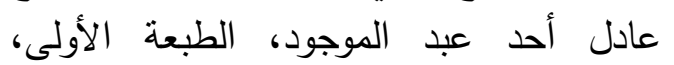
بيروت: دار الكتب العلمية.

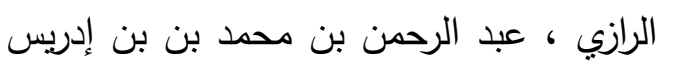
بن مهران، أبو محمد (1405)، علل العديث، بن بن إدريث،

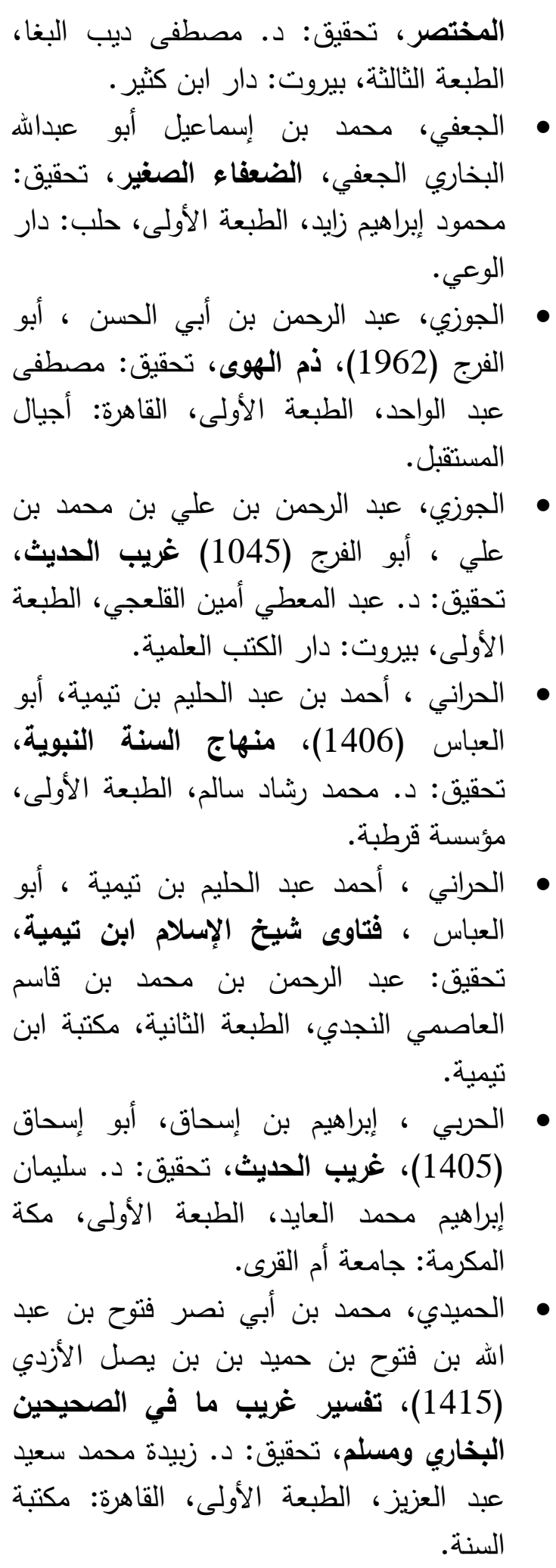


• الصوفي، أحمد بن محمد بن زياد بن بشر بن

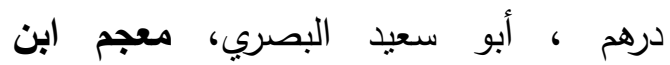

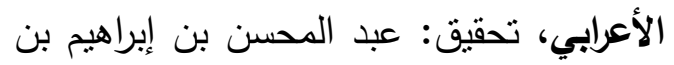

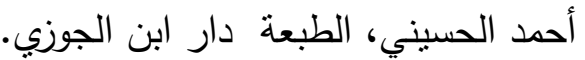

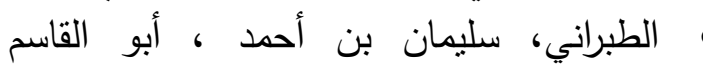

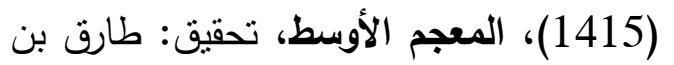

عوض الله بن محمد، القاهرة: دار الحرمين. الطبراني، سليمان بن أحمد بن أيوب أبو القاسم الحمدي

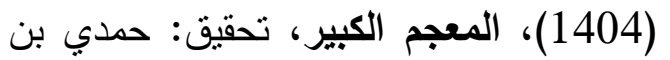

عبد المجيد السلفي، الطبعة الثانية، الموصل:

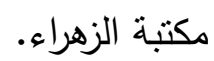

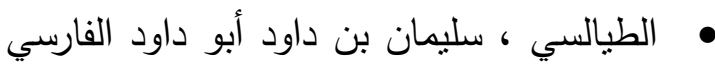

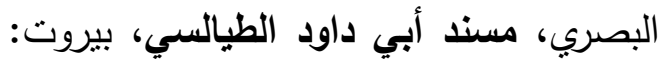

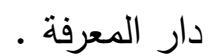

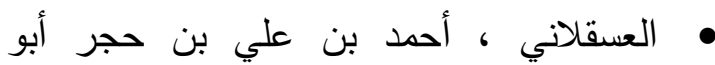
الفضل، الثنافعي (1406)، تقريب التهذيب، تحقيق: محمد عوامة، الطبعة الأولى، سوريا: دار الرشيد.

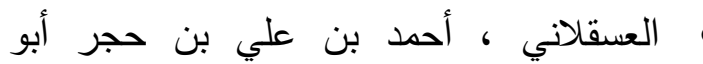
الفضل، الثافعي (1412)، الإصابة في تمييز

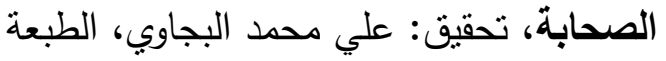

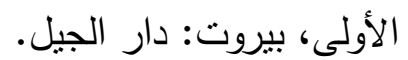

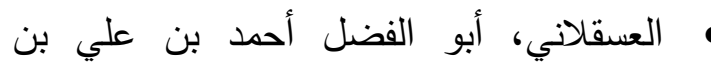

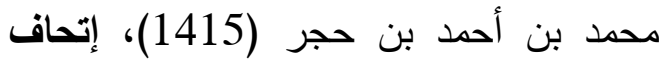
المهرة بالفوائد المبتكرة من أطراف العشرة،

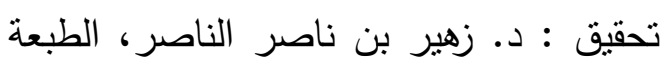

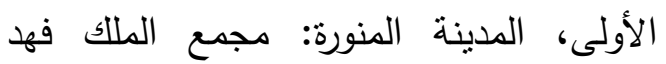
لطباعة المصحف الثربف. المديفة المنرة.

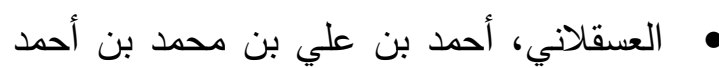
بن حجر أبو الفضل ، فتح الباري، تحقيق: عبد العزيز بن عبد اله بن باز ومحب الهب الدين تهين

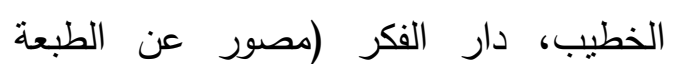

السلفية).
تحقيق: محب الدين الخطيب بيروت: دار المعرفة . ه الرازي، عبد الرحمن بن محمد بن إدريس

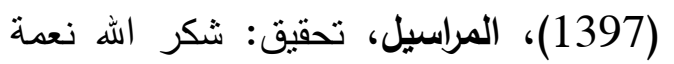

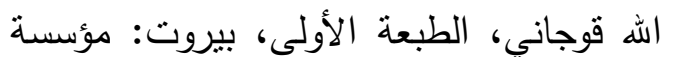

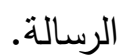

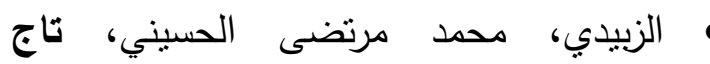

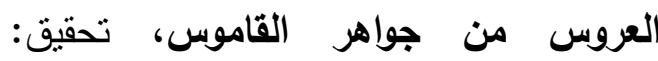
مجموعة من المحققين، دار الهداية للنشر.

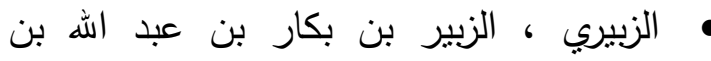

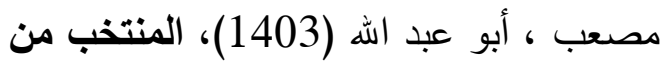

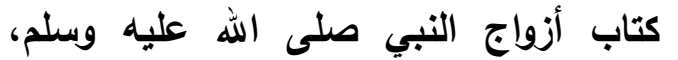
تحقيق: سكينة الثهابي، الطبعة الأولى، لئه

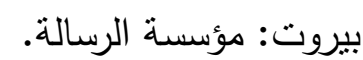
• السيوطي، عبدالرحمن بن أبي بكر أبو الفضل البرن

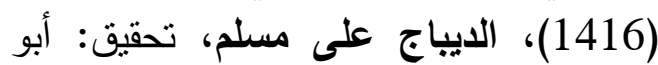

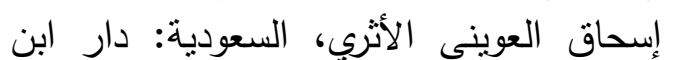
عفان. • الثافعي، محمد بن إدريس أبو عبد الله، مسند •الثافعي، بيروت: دار الكتب العلمية.

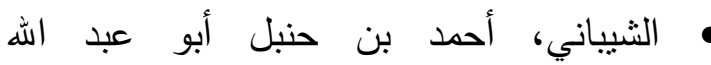

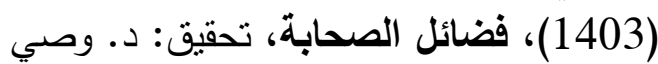

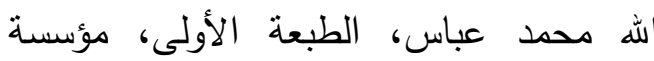

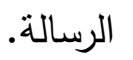
• الثيباني، أحمد بن حنبل أبو عبدالله، مسند الإمام

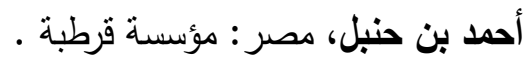

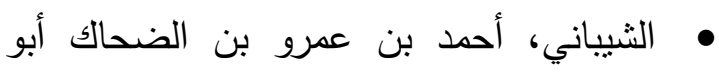
بكر (1411)، الآحاد والمثاني، تحقيق التين : د. د.

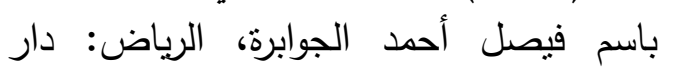
الراية. • الصنعاني، عبد الرزاق بن همام ، أبو بكر الرية

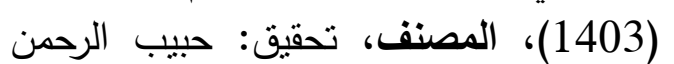
الأعظمي، الطبعة الثانية، بيروت: المكيف: المكتب المحنب

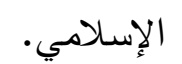


تحقيق: عبد الملك بن عبداله بن دهيش،

الطبعة الأولى، مكة المكرمة: مكتبة النهضة لهنة

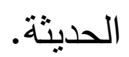

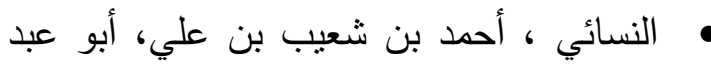

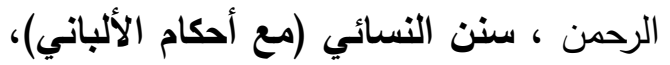

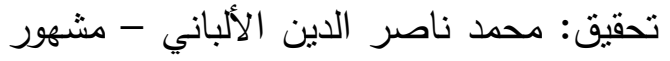
بن حسن آل سلمان، الطبعة الأولى، مكتبة الأبن المعارف للنشر والتوزيع.

• النسائي، أبو عبد الرحمن أحمد بن شعيب الفئ

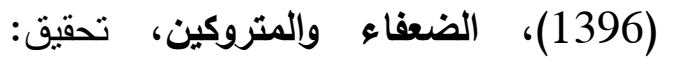
محمود إبراهيم زايد، الطبعة الأولى، حلب: داء

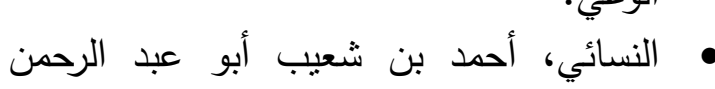
(1411)، السنن الكبرى، تحقيق: عبد الخئ الغفار سليمان البنداري، سيد كسروي حسن، الطبن، الطبنة الأولى، بيروت: دار الكتب العلمية.

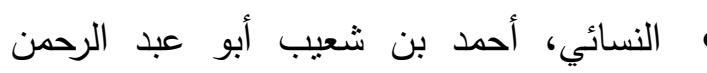

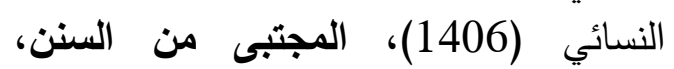
تحقيق: عبد الفتاح أبو غدة، الطبعة الثانية، حلب: مكتب المطبوعات الإسلامية.

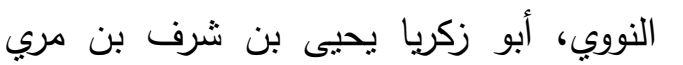

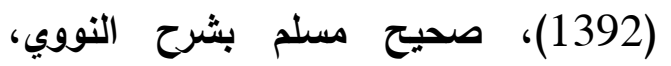
الطبعة الثانية، بيروت: دار إحياء التراث العربي. •النيسابوري، محمد بن عبداله أبو عبداله الهال

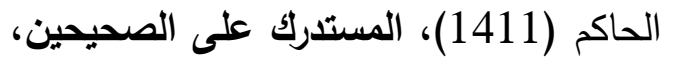

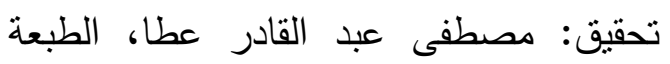
الأولى، بيروت: دار الكتب العلمية.

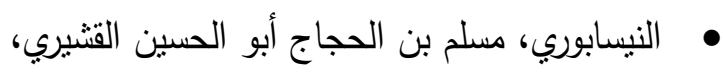

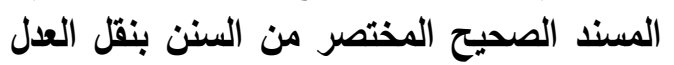

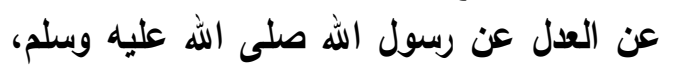

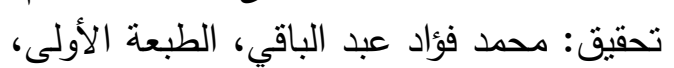
بيروت: دار إحياء التراث العربي.

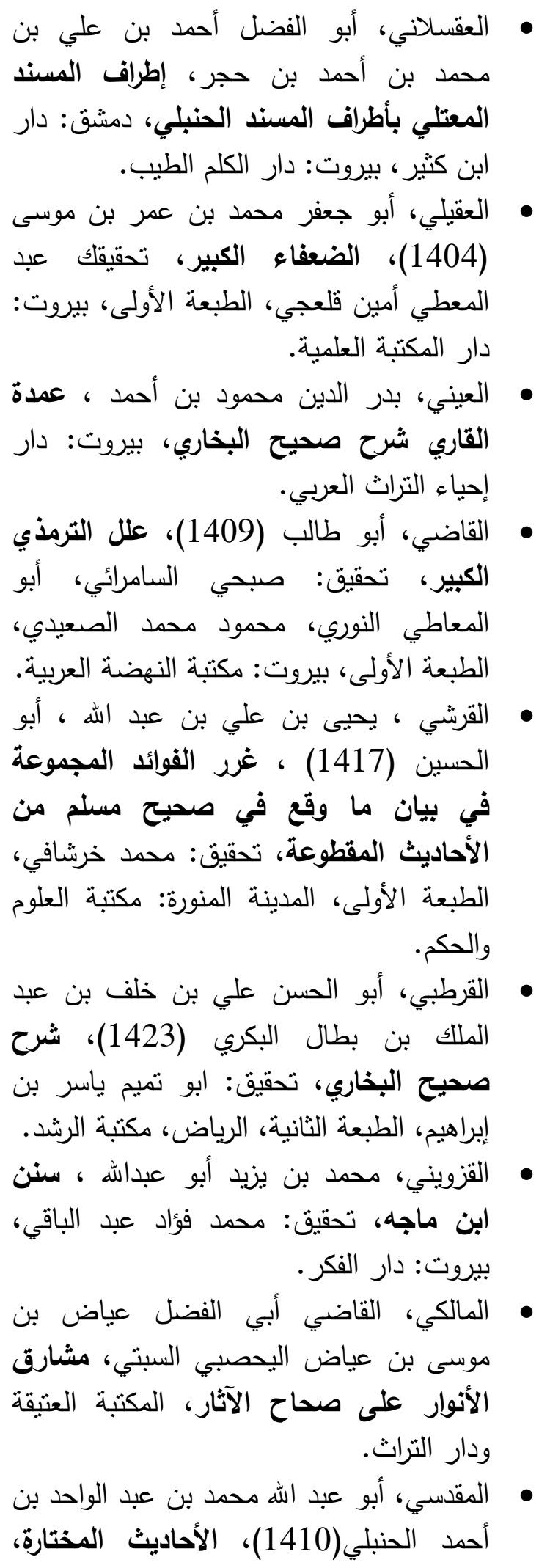


• واضح، عبد اله بن المبارك (1407)، مسند

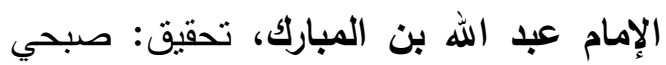
البدري السامرائي، الطبعة الأولى، الرياض: لهئ:

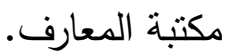
• اليدنوري ، عبد الله بن مسلم بن قتيبة،أبو محمد (1397)، غريب الحديث، تحقيق: د. د.

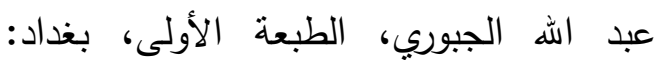

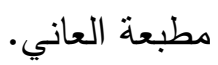

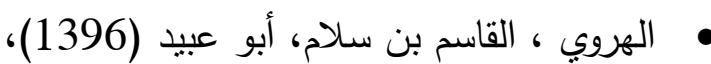

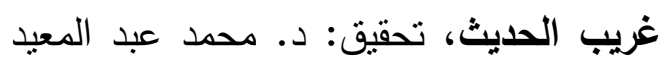
خان، الطبعة الأولى، بيروت: دار الكئن داب الكتاب

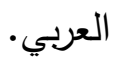

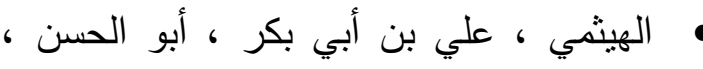

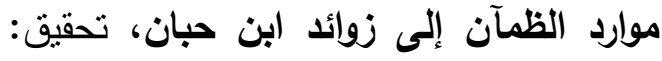

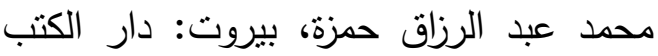
العلمية. • الهيثمي، علي بن أبي بكر (1407)، مجمع

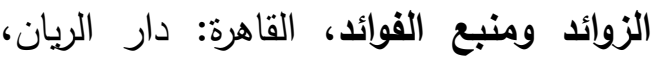

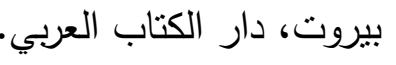




\section{Collecting and Studying the Transmitted Hadiths} Dealing with Women Jealousy

Mualla bin Musead Al-Maylabi

Abstract: This research deals with women jealousy linguistically and technically.

The research collects and studies the transmitted Hadiths on jealousy. It also clarifies the way the Prophet dealt with the question of jealousy while dealing with his wives. Keywords: Jealousy, TheProphet, Women in Islam. 